\title{
Palynology of the Toarcian-Aalenian Global Boundary Stratotype Section and Point (GSSP) at Fuentelsaz (Lower-Middle Jurassic, Iberian Range, Spain)
}

\author{
Eduardo Barrón ${ }^{\mathrm{a}, *}$, Soledad Ureta ${ }^{\mathrm{b}}$, Antonio Goy ${ }^{\mathrm{b}}$, Luis Lassaletta ${ }^{\mathrm{c}, \mathrm{d}}$ \\ anstituto Geológico y Minero de España (IGME), Ríos Rosas 23, 28003 Madrid, Spain \\ b Departamento and UEI de Paleontología (UCM-CSIC), Facultad de Ciencias Geológicas, José Antonio Nováis 2, 28040 Madrid, Spain \\ c Departamento Interuniversitario de Ecología, Facultad de Ciencias Biológicas, Universidad Complutense de Madrid, José Antonio Nováis 2, 28040 Madrid, Spain \\ d Departamento de Ecología, Universidad de Alcalá, 28871 Alcalá de Henares, Spain
}

\section{Keywords:}

Toarcian-Aalenian stratotype

palynology

biostratigraphy

environmental conditions

palaeoecology

\begin{abstract}
A B S T R A C T
The Fuentelsaz Section is located in the Castilian Branch of the Iberian Range (Guadalajara, Spain). Its exceptional Lower-Middle Jurassic transition outcrops led to its designation as the Global Boundary Stratotype Section and Point for the base of the Aalenian. The sediments of the Toarcian-Aalenian transition at Fuentelsaz are composed of marls with interbedded limestones in rhythmic alternation. Marls are dominant in the Toarcian and the Opalinum Zone up to the middle part of the Comptum Subzone. In the remaining Comptum Subzone, marly materials are scarce and limestones predominate. Sedimentation at Fuentelsaz took place over an extensive marine epeiric carbonate platform that was well connected with the open sea. In the Fuentelsaz Section, a total of 43 palynomorph taxa were recorded: 23 spore taxa, 13 pollen taxa, 4 acritarchs, 2 prasinophytes and 1 dinoflagellate cyst. The studied sediment samples were always dominated by terrestrial allochthonous miospores. In general, miospore assemblages are biased due to the transport of pollen from land or islands to the continental platform. Spheripollenites, Classopollis or indeed both pollens numerically dominate the assemblages. Other miospores appear in low numbers. Aquatic palynomorphs are also scarce; Micrhystridium lymensis is the most common. Five palynological assemblages (PA) were distinguished: PA1, PA2 and PA3 are Toarcian in age, PA4 is located at the boundary between the Toarcian and the Aalenian and PA5. This latter palynological assemblage which is lower Aalenian in age shows a strong reduction in palynomorph diversity and preservation in the Comptum Subzone. Palaeoecological analysis of the palynomorphs indicated the presence of calm, oligotrophic sea water. The palaeofloral communities of gymnosperms and vascular cryptogams-which grew in subtropical arid conditions-were poorly diversified.
\end{abstract}

\section{Introduction}

The Jurassic palynology of the Iberian Peninsula is little known. The first information was provided by Doubinguer et al. (1970) who made a reconnaissance study of the Lower Mesozoic of Europe, including the Lias of Portugal. Studies of the Portuguese Lias were continued by Adloff et al. (1974), Adloff and Doubinguer (1978), Davies (1985) and Veiga de Oliveira et al. (2007). Palynological studies of the Lusitanian Basin, however, have mainly focused on the Middle and Upper Jurassic (Riley, 1974; Boland, 1986; Van Erve and Mohr, 1988; Mohr and Schmidt, 1988; Mohr, 1989; Smelror et al., 1991; Mohr and Schultka, 2000; Barrón and Azerêdo, 2003).

Little palynological information exists on the Lower Jurassic of Spain. Indeed, the plant life that reigned in the west of the Southern European Province of the Eurosinian Region (sensu Vakhrameev,
1991) during this period is almost completely unknown, even though a large number of sections have been well studied from sedimentological, stratigraphic and palaeontological points of view (Vera, 2004; Gómez and Goy, 2005). The palynological study of the Spanish Lias has recently begun in sections in Asturias, the BasqueCantabrian Basin and the Iberian Range (Barrón et al., 1999a, b, 2006; Gómez et al., 2007). The few studies that exist on Middle Jurassic palynomorphs from Spain were performed by Fenton and Fisher (1978) and Smelror et al. (1991), and focus on Bathonian to Callovian dinoflagellate cyst assemblages from northeastern Spain and the Iberian Range.

The section of Fuentelsaz was formally stablished as Global Boundary Stratotype Section and Point (GSSP) for the base of the Aalenian stage in the 31st International Geological Congress (Rio de Janeiro, Brazil, 2000) by the International Commission on Stratigraphy. It has been exhaustively studied from lithological, sedimentological, stratigraphic, palaeontological, magnetostratigraphic, geochemical, mineralogical and isotopic points of view. Palaeontological studies include groups such as ammonites, brachiopods, 
ostracods, nannofossils, foraminifers and palynomorphs (Goy and Ureta, 1987, 1991; Martínez, 1992; García-Joral and Goy, 1994; Goy et al., 1994, 1996; Herrero and Canales, 1997; Perilli, 1999; Cresta et al., 2001). The richness of successive ammonoid assemblages allowed a high resolution biostratigraphic scale to be established, which permits detailed correlations be made with other Jurassic sections (Goy and Ureta, 1987, 1991; Goy et al., 1994, 1996, 1999; Cresta et al., 2001). Biostratigraphic event based in the ammonite evolution (the first appearance of the graphoceratid genus Leioceras) marks the Lower-Middle Jurassic boundary at the base of level FZ107 in Fuentelsaz (Goy and Ureta, 1987, 1991; Goy et al., 1994, 1996, 1999; Cresta et al., 2001).

To date, only a few short palynological contributions regarding Fuentelsaz have been published (Goy et al., 1996, 1999; Cresta et al., 2001), focusing on assemblages from a few levels near the ToarcianAalenian transition. These assemblages, which are dominated by the pollen grains of gymnosperms, contain conspicuous amounts of acritarchs. Spores of vascular cryptogams and the phycomes of prasinophytes are scarce. More recently, Peyrot et al. (2007a) used confocal microscopy to study Classopollis in the Fuentelsaz Section. The present paper reports a complete study of the palynological content of the Late Toarcian-Early Aalenian rocks outcropping in the Fuentelsaz Section. Qualitative and quantitative analyses were performed in order to identify palynological assemblages, which were calibrated using the above ammonoid-based biostratigraphic scale. These analyses also allowed the inferred assemblages to be compared with contemporaneous counterparts in other parts of Europe and North Africa. The palaeoenvironmental conditions reflected by the section were also analysed.

\section{Geological setting}

The Fuentelsaz section is situated in the central sector of the NW-SE trending Iberian Range which is an intracontinental Alpine belt with Variscan basement and Mesozoic and Cenozoic cover. The section is located at about $0.5 \mathrm{~km}$ north of the Fuentelsaz village, Guadalajara province (Fig. 1A). It has previously been described by Comas-Rengifo and Goy (1983), Goy and Ureta (1987, 1991), García-Joral and Goy (1994), Goy et al. $(1994,1996)$ and Cresta et al. (2001).

At Fuentelsaz the Upper Toarcian (Mactra, Aalensis and Buckmani subzones of the Aalensis Zone) and Lower Aalenian (Opalinum and Comptum subzones of the Opalinum Zone) (Fig. 1B,C) are represented by a ( $41.5 \mathrm{~m}$ of thick) complete succession of alternating limestones (mudstones and bioclastic wackestones, occasionally packstones) and marls. The lower and middle parts of the section, which are markedly marly (levels 1 to 153), correspond to the upper part of the Turmiel Formation (Goy et al., 1976), whereas the upper part, which is predominantly calcareous (levels 154 to 205), belongs to the lower part of Casinos Formation (Gómez et al., 2003) (Fig. 1B).

The depositional environment at this time correspond to a faultbounded subsiding block, within in a $\mathrm{N}-\mathrm{S}$ trending marine epeiric carbonate platform well connected with the open sea until the late Comptum Biochrone (Fig. 2B). Facies pattern and vertical evolution observed in the Fuentelsaz section reveal a striking similarity to many others outcrops in the Iberian Range where an important episode of extensional faulting has been recognized in the late Early Aalenian. Synsedimentary extensional tectonic activity is documented by a drastic increase in the net accumulation rate $(12 \mathrm{~m} / \mathrm{Ma})$ during the latest Comptum Biochrone, and is especially well recorded at the Fuentelsaz section (see García-Frank et al. 2008).

\section{Materials and methods}

One hundred and two sediment samples from the Fuentelsaz Section were examined. All samples were prepared following the standard palynological technique (Batten, 1999; Peyrot et al., 2007a). Sixty nine samples yielded palynological contents: 66 from the Turmiel Formation (from the Insigne to Comptum p.p. Subzones) and three from the Casinos Formation (in the Comptum Subzone) (Figs. 1B, 3-4).

To determine the floral turnover in response to palaeoenvironmental changes, the palynomorphs were organised according to their botanical affinities in accordance with the data of Harris (1974), Balme (1995), Batten and Dutta (1997) and Abbink (1998) (Table 1). Miospores were organised into two groups based on the ecological preferences (mainly water needs) of the plants that produced them, and the adaptability of these plants to more or less dry environments.

A synthetic pollen diagram (Fig. 5) was constructed using Tilia and Tilia Graph 2.0.b4 and TGView 2.0.2 software (Illinois State Museum, Springfield, USA) to determine the quantitative variation of taxa or groups of taxa over the succession and the palynological assemblages (PA).

The palynological data was examined using correspondence analysis (CA) (Benzécri, 1973). This multivariate ordination method has been used with success in many palaeoecological studies of the Mesozoic (Mussard et al., 1997; Wagstaff et al., 2006; Herkat, 2007; Peyrot et al., 2007b). The CA included all the marine and terrestrial taxa documented except for those present only in a single stratigraphic level (Fig. 6); their exceptional nature would only bring noise into the analysis. To interpret the significance of the axes generated by $\mathrm{CA}$, the taxa with the best quality of representation were determined (i.e., those with the highest absolute and relative contributions).

A second CA (Fig. 7) was undertaken to synthesise the information in the terrestrial palynomorph data set with the aim of obtaining gradients that would situate the stratigraphic levels as a function of the covariance of their taxa. Based on the information in Table 1 seven taxa groups were selected.

To determine the distribution of the abundance of each taxa group in the palynological assemblages (PA) throughout the section, abundances were divided by the number of levels in which each taxa group appeared. Finally, the proportion of the total number of miospores of each taxa group represented in each PA was calculated (Table 2). All statistical analyses were performed using STATISTICA 6.0 software (StatSoft Inc., 2001).

\section{Palynological study}

The studied palynomorphs occurred in marls and marly limestones. No palynomorphs were seen in the limestone proper of the Comptum Subzone (Figs. 3-4), where it is the only type of rock. The youngest palynomorphs of Fuentelsaz were recorded in level FZ166. A similar pattern is seen in the record for other fossil groups such as brachiopods, foraminifera and calcareous nanofossils (García-Joral and Goy, 1994; Herrero and Canales, 1997; Perilli, 1999).

A total of 23 spore and 13 pollen types, four acritarchs, two prasinophytes and one dinoflagellate cyst were found (Table 1). Poorly preserved, undetermined scolecodonts and the organic linings of foraminifera were also found at levels FZ109 and FZ29-FZ35 respectively. Miospores were the primary focus of the study owing to their predominance in the analysed samples. A complete systematic study of the palynoflora was not contemplated since the recorded taxa have been sufficiently treated elsewhere (Eisenack, 1957; Couper, 1958; Nilsson, 1958; de Jersey, 1960; Briche et al., 1963; Döring, 1965; Wall, 1965; Schulz, 1967; Srivastava, 1966; Tralau, 1968; Pocock, 

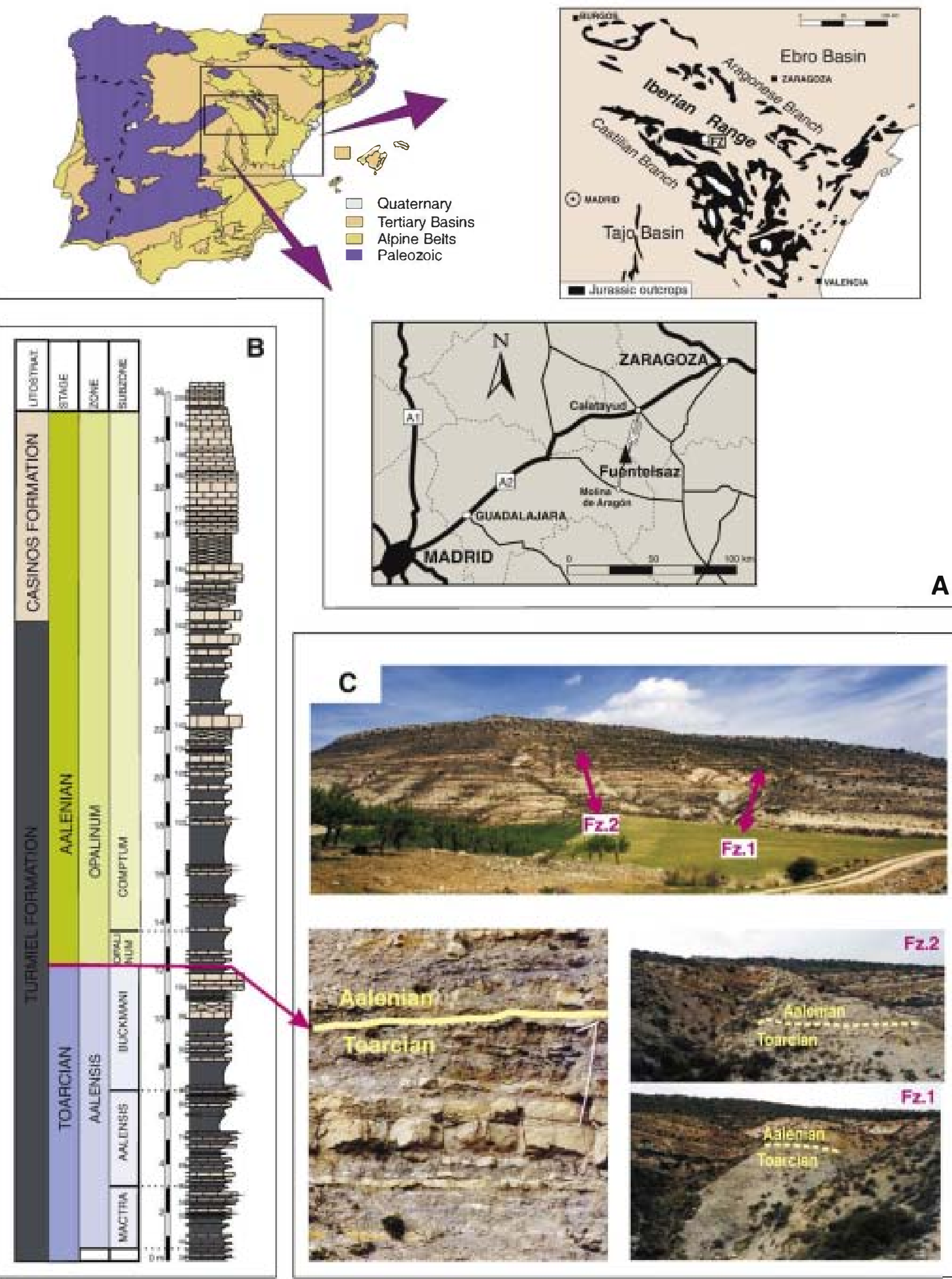

Fz.2

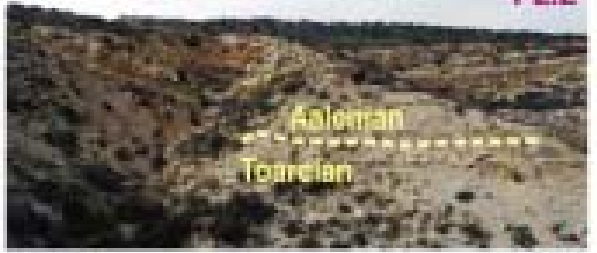

Fz.1

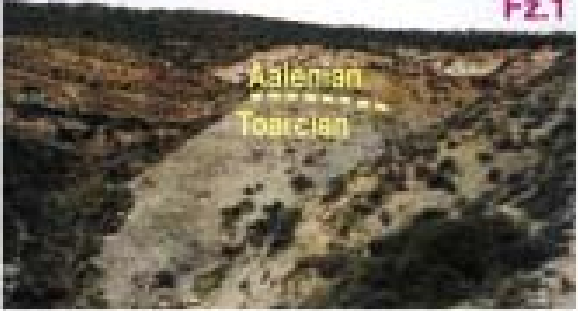




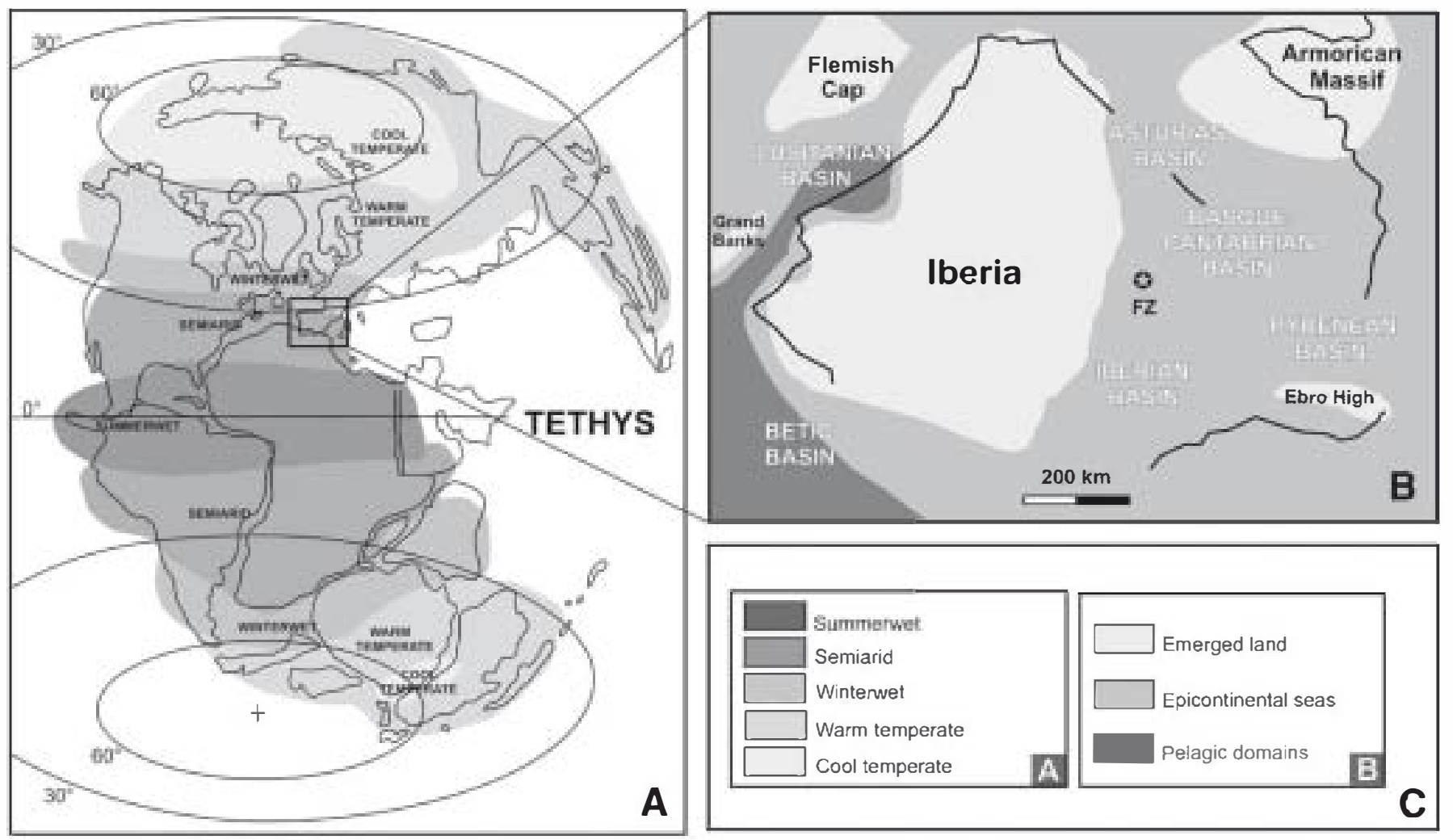

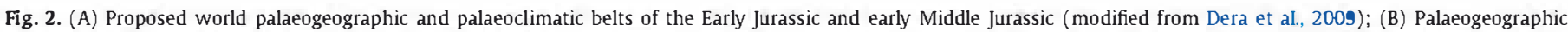

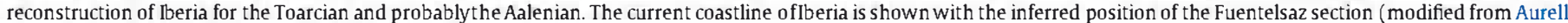
et aI., 2003 and Gómez and Goy,

1970; Guy, 1971; Tralau and Artursson, 1972; Filatoff, 1975; Vigran and Thusu, 1975; van Erve, 1977; Boutet, 1981; Guy-Ohlson, 1982; Riding, 1983; Davies, 1985; Guy-Ohlson, 1986; Srivastava, 1987; Dybkjaer, 1991; Boulter and Windle, 1993; Liu, 2000; Peyrot et al. 2007a).

The palynological assemblages at the Toarcian-Aalenian transition in the studied outcrop are characterised by a low diversity of palynomorphs. This is remarkable since acritarchs and dinoflagellate cysts are usually common and diverse in European Jurassic marine rocks (Williams and Bujak, 1985; Stover et al., 1996; Fauconnier, 1997). Only the species Micrhystridium lymensis (Plate I, Fig. 2) appears frequently in almost all levels, whereas Cymathiosphaera cf. pachytheca (Plate I, Fig. 1), although present throughout the succession, appears only scarcely (Figs. 3-4). In addition, very abundant wind-dispersed pollen grains related to gymnosperms numerically dominate the assemblages. The species Spheripollenites psilatus (Plate II, Fig. 6) was the most abundant palynomorph in all the samples studied. However, its presence is less notable at the base of the succession in the Insigne Subzone. Classopollis torosus is well represented in all Toarcianlevels and in the Opalinum Subzone of the Aalenian, but not in the Comptum Subzone (Peyrot et al., 2007a). The percentages of $C$ torosus and those of Circumpolles gen. et sp. indet. are notable in the Insigne Subzone, being higher than those of $S$. psilatus. In general, the pollen grains of Cheirolepidiaceae are present in percentages higher than $30 \%$ in the Insigne, Pseudoradiosa and Mactra Subzones as well as in the oldest half of the Aalensis Subzone. Similarly they are found in high percentages in the Toarcian-Aalenian transition. In contrast, bisaccate, monosaccate, inaperturate and monosulcate pollen grains are not well represented throughout the succession (Figs. 3-5).

Aquatic palynomorphs are in low numbers $(<15 \%)$ compared to those of the genera Spheripollenites and Classopollis. The highest percentages of this group, mainly represented by Micrhystridium lymensis, occur in the Aalensis Subzone and at the lower part of the Buckmani and Comptum Subzones. Spores of vascular cryptogams are always more scarce than pollen grains and aquatic over the succession (Fig. 5). Spores are better represented in the Toarcian, with 24 species, than in the Aalenian, for which only 12 species were recorded. Cyathidites australis (Plate II, Fig. 3) and C. minor are the most abundant species, though Uvaesporites argenteaeformis and Kraeuselisporites reissingeri (Plate II, Fig. 2) are conspicuous in the Toarcian.

The first $C A$, performed with the 43 documented terrestrial and marine taxa, revealed a major direction of variation explaining $77.3 \%$ of the total variance (Fig. 6). The study of the distribution of the taxa and their absolute and relative contributions revealed a first axis explaining a gradient of variation between the terrestrial taxa: Spheripollenites at the negative extreme, and $C$. torosus at the positive extreme. The second axis accounted for much less of the variance (7.9\%) and explained only the abundance of the marine taxon Micrhystridium lymensis; the stratigraphic levels with a great abundance of the acritarch were situated at the extreme negative end of the axis. Level IFZ-117, which had a very high negative value on the second axis, was that with the greatest abundance of $M$. lymensis (186 specimens). The remaining levels had much lower values on the second axis and showed an abundance of $M$. lymensis, but always lower than that of IFZ-117. The levels with negative values on the second axis had 20-100 miospores, while those on the positive side had 0-20.

\subsection{Palynological assemblages}

Based on changes recorded for the palynological components and their proportions, five successive palynological assemblages were identified in the studied levels of the Late Toarcian and Early Aalenian. 

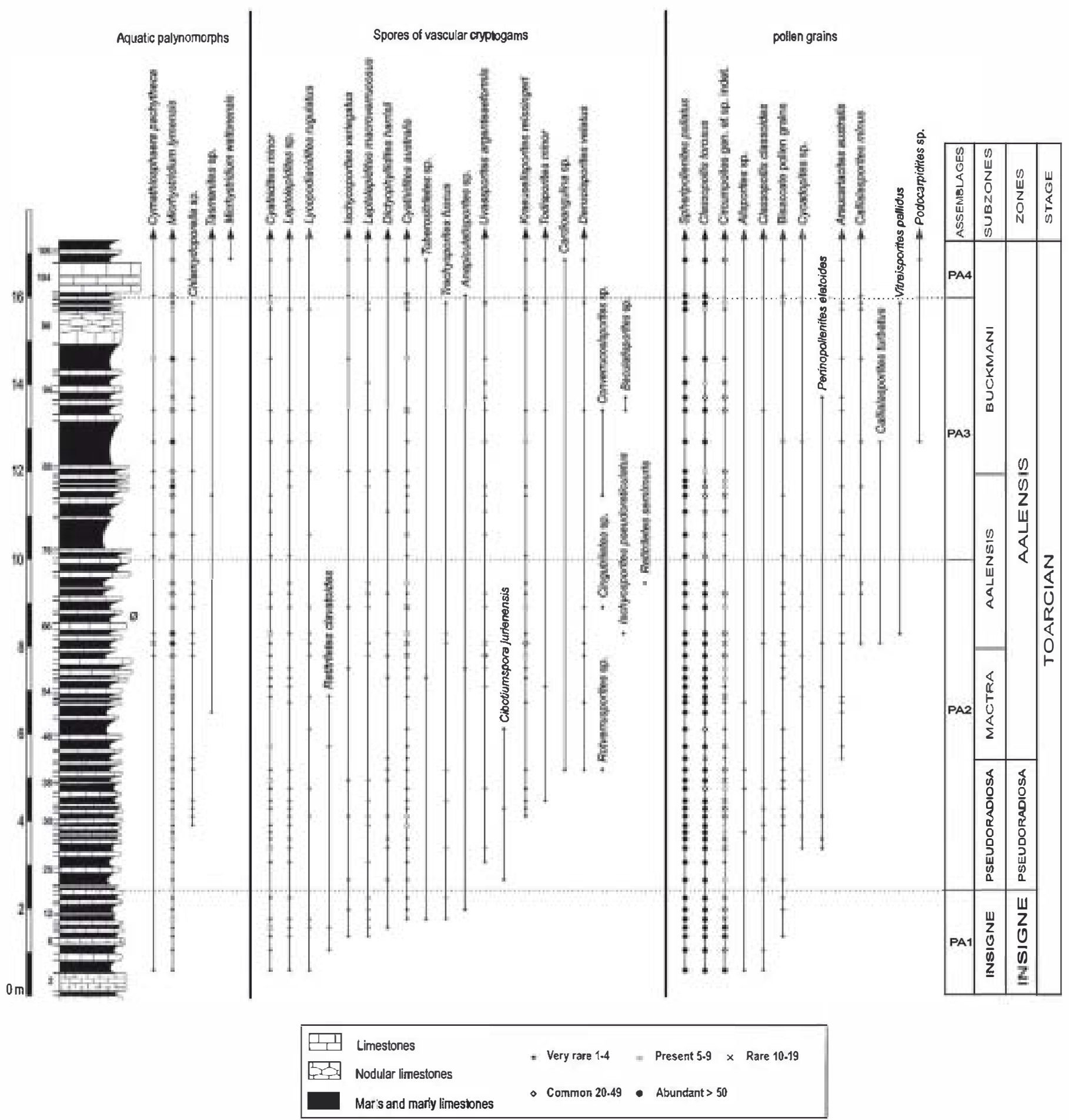

Fig. 3. Stratigraphic succession of the Toarcian of the Fuentelsaz Section, showing the distribution of palynomorphs.

These assemblages are here described for the first time in the Iberian Range.

The second CA, performed with the terrestrial taxa groups, revealed a first axis that accounted for even more of the variance than in the first CA (94.8\% of variance) (Fig. 7). On this first axis, the taxa groups with negative coordinates were Araucariaceae and Spheripollenites, while Cheirolepidiaceae, Pteridospermophyta and Cyatheaceae/Dicksoniaceae/Dipteridaceae had positive coordinates. The hydrophytics, Cycadales/Bennnetittales/Ginkgoales, Selaginellaceae and bisaccate Coniferophyta lay close to the origin.
The first axis explains the gradient between Spheripollenites and Cheirolepidiaceae, taxa with high absolute and relative contribution values. The stratigraphic levels situated at the extreme negative end of the first axis show a large abundance of Spheripollenites and low abundances of Cheirolepidiaceae-just the opposite to that seen for the levels at the positive extreme. The first axis shows a separation of the PAs, which are therefore stratified according to this gradient (Fig. 7). The second axis explains only $1.6 \%$ of the variance and is related to the variation gradient between Spheripollenites and Cheirolepidiaceae. 


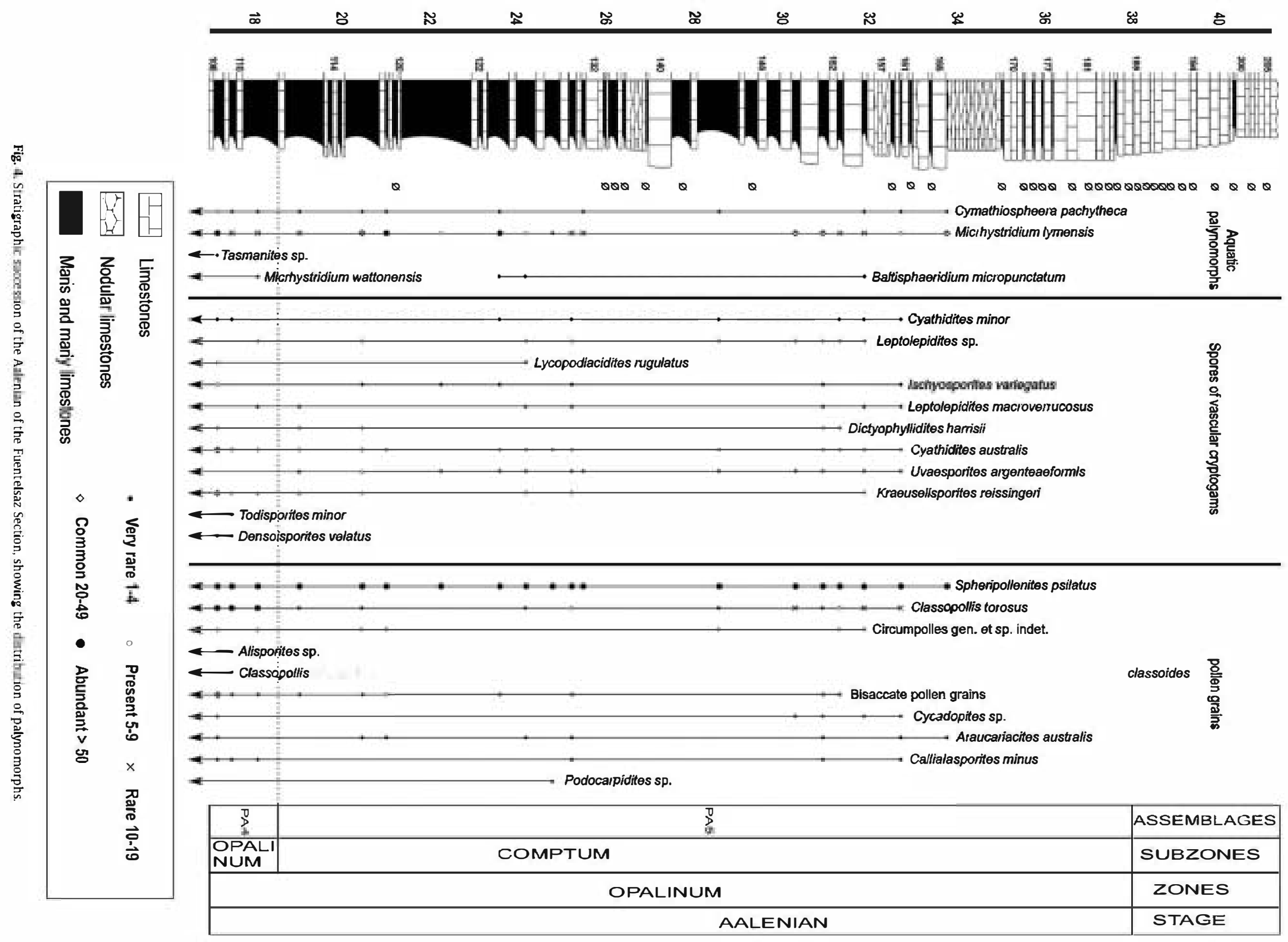




\begin{tabular}{|c|c|c|}
\hline & Botanical affinity & General ecology \\
\hline \multicolumn{3}{|l|}{ Aquatic palynomorphs } \\
\hline Baitisphaeridium cf. micropunctatum Wall 1965 & Acritarcha & Brackish-marine \\
\hline Chiamydophorella $s p$. & Dinoflagellata & Marine \\
\hline Cymatiosphaer cf. pachythec Eisenack 1957 & Prasinophyceae? & Brackish-marine \\
\hline Micrhystridium intromittum Wall 1965 & Acritarcha & Brackish-marine \\
\hline Micrhystridium lymensis Wall 1965 & Acritarcha & Brackish-marine \\
\hline Micrhystridium wattonensis Wall 1965 & Acritarcha & Brackish-marine \\
\hline Tasmanites sp. & Prasinophyceae & Brackish-marine \\
\hline \multicolumn{3}{|l|}{ Miospores } \\
\hline \multicolumn{3}{|l|}{ Spores } \\
\hline Anapiculatisporites $\mathrm{sp}$. & l.ycophyta & Hygrophilous \\
\hline Baculatisporites sp. & Pteridophyta (Osmundaceae) & Hygrophilous \\
\hline Cardiongulina $\mathrm{sp}$. & Pteridophyta & Hygrophilous \\
\hline Cibotiumspora jurienensis (Balme 1957) Filatoff 1975 & Pteridophyta (Cyatheaceae/Dicksoniaceae) & Hygrophilous \\
\hline Cingutriletes sp. & Bryophyta & Hygrophilous \\
\hline Converrucosisporites sp. & Pteridophyta (Cyatheaceae/Dipteridaceae) & Hygrophilous \\
\hline Cyathidites australis Couper 1953 & Pteridophyta (Cyatheaceae/Dicksoniaceae/Dipteridaceae) & Hygrophilous/Xerophilos? \\
\hline Cyathidites minor Couper 1953 & Pteridophyta (Cyatheaceae/Dicksoniaceae/Dipteridaceae) & Hygrophilous/Xerophilos? \\
\hline Densoisporites velatus Weyland et Krieger 1953 emend. Dettmann 1963 & l.ycophyta (Pleuromeiaceae/Selaginellaceae) & Hygrophilous \\
\hline Dictyophyllidites harisii Couper 1958 & Pteridophyta (Dipteridaceae/Matoniaceae) & Hygrophilous \\
\hline Ischyosporites pseudoreticulatus (Couper 1958) Döring 1965 & Pteridophyta (Schizaeaceae) & Hygrophilous \\
\hline Ischyosporites variegatus (Co uper 1958) Schulz 1967 & Pteridophyta (Schizaeaceae) & Hygrophilous \\
\hline Kraeuselisporites reissingeri (Harris 1957) Morbey 1975 & l.ycophyta (Selaginellaceae) & Hygrophilous/Xerophilos? \\
\hline Leptolepidites macroverrucosus Schulz 1967 & l.ycophyta & Hygrophilous \\
\hline Leptolepidites sp. & lycophyta & Hygrophilous \\
\hline Lycopodiacidites rugulatus (Couper 1958) Schulz 1967 & lycophyta & Hygrophilous \\
\hline Retitriletes ciavatoides (Couper 1958) Döring, Krutzsch, Mai and Schulz in Krutsch 1963 & lycophyta & Hygrophilous \\
\hline Retitriletes semimuris (Danzé and laveine, 1963) Mc Kellar 1974 & l.ycophyta & Hygrophilous \\
\hline Rotverrusporites sp. & l.ycophyta (Selaginellaceae) & Hygrophilous \\
\hline Todisporites minor Couper 1958 & Pteridophyta (Osmundaceae) & Hygrophilous \\
\hline Trachysporites fuscus Nilsson 1958 & Pteridophyta & Hygrophilous \\
\hline Tuberositriltes sp. & Pteridophyta & Hygrophilous \\
\hline Uvaesporites genteaeformis (Bolchovitina 1953) Schulz, 1967 & l.ycophyta (Selaginellaceae) & Hygrophilous/Xerophilos? \\
\hline \multicolumn{3}{|l|}{ Pollen grains } \\
\hline Alisporites sp. & Pteridospermophyta (Peltaspermales) & Hygrophilous \\
\hline Araucariacites australis Cookson, 1947 & Coniferophyta (Araucariaceae) & Xerophilous \\
\hline Callialasporites minus (Tralau 1968) Guy 1971 & Coniferophyta (Araucariaceae) & Xerophilous \\
\hline Callialasporites turbatus (Balme 1957) Schulz 1967 & Coniferophyta (Araucariaceae) & Xerophilous \\
\hline Classopollis classoides Pflug 1953 emend. Pocock and Jansonius, 1961 & Coniferophyta (Cheirolepidiaceae) & Xerophilous \\
\hline Classopollis torosus (Reissinger 1950) Couper emend. Burger 1965 & Coniferophyta (Cheirolepidiaceae) & Xerophilous \\
\hline Circumpolles gen. et sp. indet. & Coniferophyta (Cheirolepidiaceae) & Xerophilous \\
\hline Cycadopites sp. & Ginkgoales/Cycadales/Bennetitales & Xerophilous \\
\hline Perinopollenites elatoides Couper, 1958 & Coniferophyta (Taxodiaceae) & Hygrophilous \\
\hline Podocalpidites sp. & Coniferophyta (Podocarpaceae) & Xerophilous \\
\hline Spheripollenites psilatus Couper 1958 & Unknown Coniferophyta/Bennetitales & Xerophilous \\
\hline Undetermined bisaccate pollen grains & Unknown Coniferophyta & Xerophilous \\
\hline Vitreisporites pallidus (Reissinger 1950) Nilsson 1958 & Pteridospermophyta (Caytoniales) & Hygrophilous \\
\hline
\end{tabular}

\subsubsection{Palynological assemblage 1}

Palynological assemblage 1 (PA1) coincides with the Insigne Subzone, and includes levels FZ3 to FZ15 (Fig. 3). The levels of PA1 lie at the positive extreme of the first axis of the second CA (Fig. 7), indicating them to be characterised by the predominance of pollen of Cheirolepidiaceae over Spheripollenites (mainly levels FZ3 to FZ11). This is the only PA in which this is seen (Fig. 8). In addition, low numbers of aquatic palynomorphs and other pollen grains are seen (Fig. 5). No taxa group shows its maximum abundance in this PA; indeed, Selaginellaceae, Cycadales/Bennnetittales/Ginkgoales and Araucariaceae are completely absent (Fig. 3; Table 2). The family Cheirolepidiaceae is mainly represented in PA1 by Classopollis torosus, though Circumpolles sp. et gen. indet. is conspicuous in levels FZ3, FZ7 and FZ9. Percentages of Cheirolepidiaceae decrease in levels FZ13FZ15, with $S$. psilatus predominant over the stratigraphic succession from the mentioned levels. In contrast to the reducing percentages of Cheirolepidiaceae, spore diversity increases progressively but with very low numbers of specimens per level. The spores identified were Anapiculatisporites sp., Cyathidites minor, C australis, Dictyophyllidites harrisii (Plate I, Fig. 4), Ischyosporites variegatus (Plate I, Fig. 6),
Leptolepidites macroverrucosus (Plate I, Fig. 8), Leptolepidites sp. (Plate II, Fig. 1), Lycopodiacidites rugulatus (Plate II, Fig. 4), Retitriletes clavatoides, Trachysporites fuscus and Tuberosistriletes sp. Among the bisaccate pollen grains identified in this assemblage, only the genus Alisporites could be determined at level FZ3.

\subsubsection{Palynological assemblage 2}

Palynological assemblage 2 (PA2) comprises the Pseudoradiosa and the Mactra Subzones as well as the lower half of the Aalensis Subzone between levels FZ19 and FZ73 (Fig. 3). The levels of this PA lie in an intermediate position on the first axis of the second CA (Fig. 7). This indicates this assemblage to be numerically dominated by $S$. psilatus, though Cheirolepidiaceae (mainly $C$ torosus) usually accounts for more than $20 \%$ of the palynomorphs present, reaching $50 \%$ in the Pseudoradiosa Subzone (Fig. 5). The aquatic palynomorphs slightly increase their presence due to $M$. lymensis. The other pollen grains increase in proportion slightly through the contribution of Cycadopites sp., Perinopollenites elatoides and undetermined bisaccate pollen grains. Cycadales/Bennetittales/Ginkgoales show their 


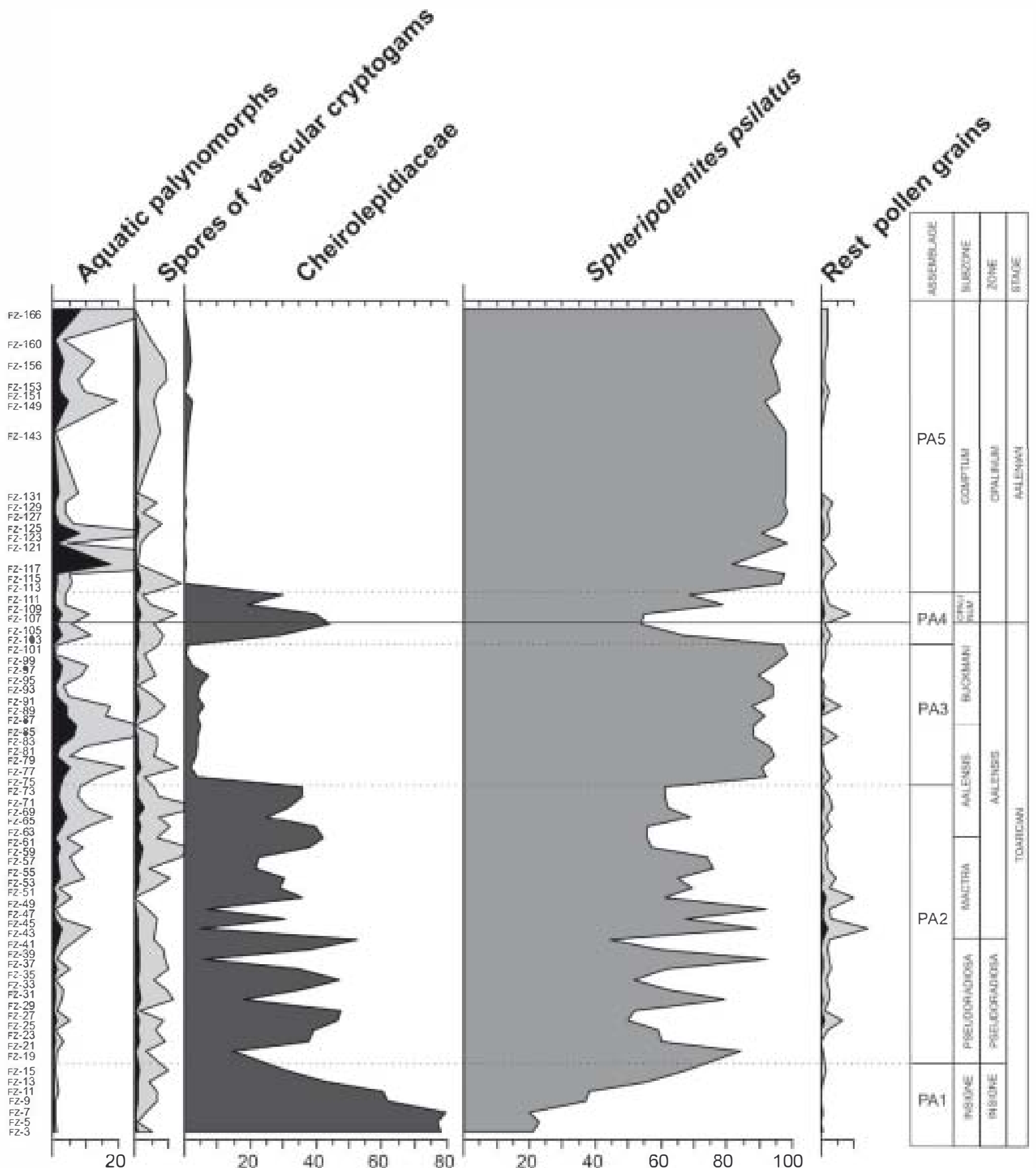

Fig. 5. Synthetic pollen diagram of the Fuentelsaz Section. See text for details.

maximum abundance values in this association (Table 2). The spores of vascular cryptogams show percentages similar to those seen in PA1.

An increase in diversity can be seen over PA2. The aquatic palynomorphs Chlamydophorella sp. (Plate I, Fig. 3) and Tasmanites sp. are present in small amounts. Concretely, the Chlamydophorella dinocysts resemble to the Cretaceous species $C$. ambigua Deflandre and C. discreta Clarke and Verdier (Clarke and Verdier, 1967; Fauconnier and Masure, 2004).
The number of spores in PA2 is greater than in PA1 and includes all those recorded in PA1 plus Cardioangulina sp., Cibotiumspora jurienensis, Cingutriletes sp., Densoisporites velatus, Ischyosporites pseudoreticulatus, Kraeuselisporites reissingeri (Plate II, Fig. 2), Retitriletes semimuris, Rotverrusporites sp., Todisporites minor and Uvaesporites argenteaeformis. The greatest presence of spores in the succession is seen in the transition of the Mactra and the Aalensis Subzones, owing to the abundance of Cyathidites australis (Plate II, 


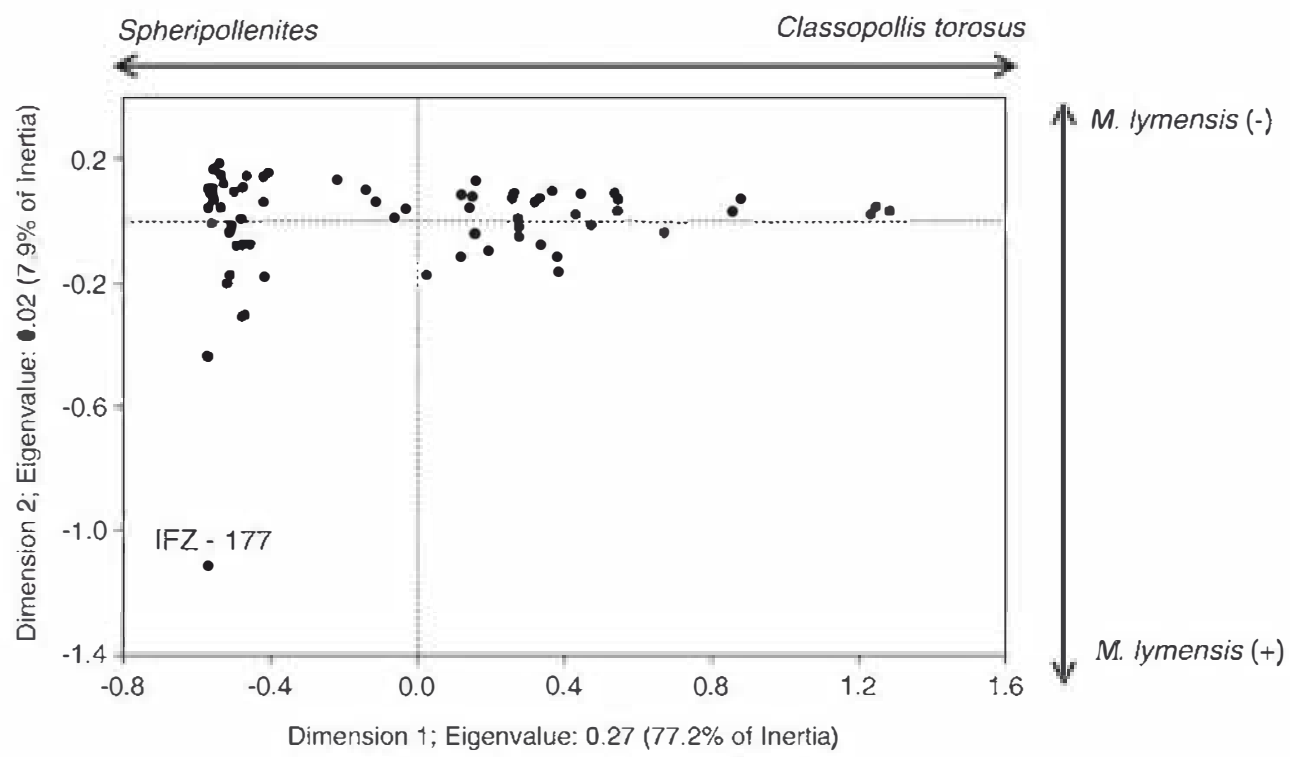

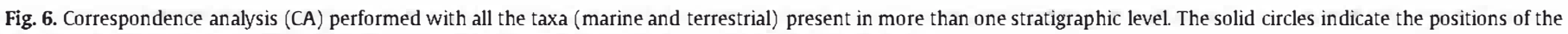
levels on axes I and II. Also included are those taxa with the best quality of representation on each axis.

Fig. 3), $K$ reissingeri and U. argenteaeformis. The last occurrences of the species Retitriletes clavatoides and $C$ jurienensis are recorded in the Mactra Subzone. The single occurrence of Rotverrusporites sp. is restricted to the top of the Pseudoradiosa Subzone, whereas Micrhystridium intromittum (Plate I, Fig. 7), Cingutriletes sp., I. pseudoreticulatus and $R$. semimuris only occur in the Aalensis Subzone. Coinciding with the Pseudoradiosa Subzone, Cycadopites sp. and Perinopollenites elatoides are recorded for the first time. Araucariacites australis appears from the Mactra Subzone to the top of the succession, and Callialasporites minus, C turbatus (Plate II, Fig. 5) and Vitreisporites pallidus (Plate II, Fig. 7) have their first appearances in the Aalensis Subzone.

\subsubsection{Palynological assemblage 3}

Palynological assemblage 3 (PA3) is developed within the upper half of the Aalensis Subzone and throughout most of the Buckmani Subzone, between levels FZ75 to FZ101 (Fig. 3). PA3 shows percentages of
S. psilatus of over $85 \%$ in all levels. The pollen of Cheirolepidiaceae decreases to below $10 \%$. Thus, this association lies at the negative extreme of the first axis of the second CA (Figs. 7-8). No taxa group shows its maximum abundance in this PA, and Cheirolepidiaceae shows only a very small presence (Fig. 3; Table 2 ). The aquatic palynomorphs slightly increase their presence at the boundary between the Aalensis and the Buckmani Subzones (Fig. 5). This assemblage is also characterised in the Buckmani Subzone by the occurrence of Baculatisporites sp., the first record of Podocarpidites sp., and the last occurrences of Callialasporites turbatus (Plate II, Fig. 5), Chlamydophorella sp. (Plate I, Fig. 3), Converrucosisporites sp., Perinopollenites elatoides and Vitreisporites pallidus (Plate II, Fig. 7).

\subsection{Palynological assemblage 4}

Palynological assemblage 4 (PA4) is represented at the boundary between the Buckmani and Opalinum Subzones as well as throughout the Opalinum Subzone (which includes levels FZ103 to FZ111)

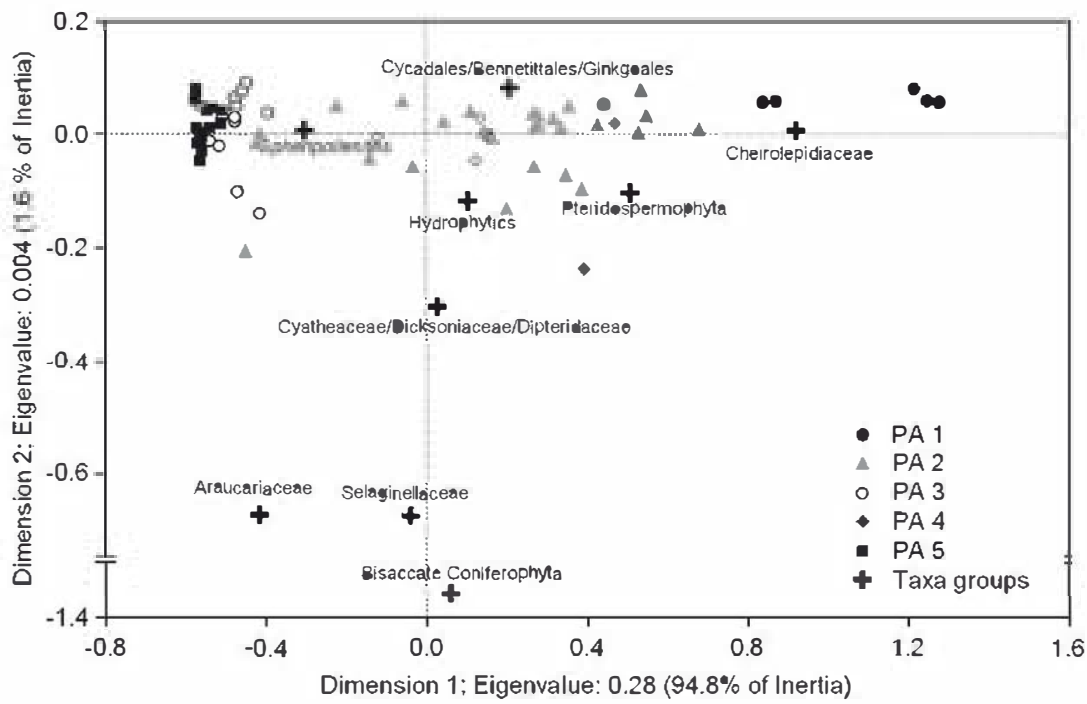

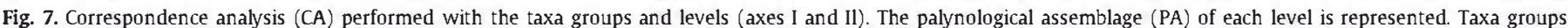

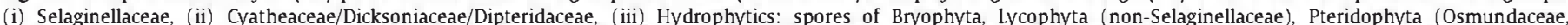

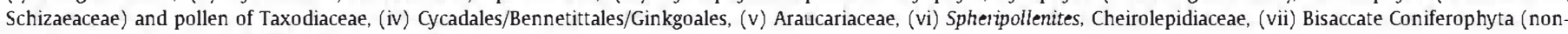
Pteridospermophyta) and (viii) Pteridospermophyta. 
Table 2

Proportion of the total number of miospores of each taxa group represented in each PA: $<15 \%,+15-30 \%,-30-50 \%, \mathbf{\Delta}>50 \%, \boldsymbol{\square} 100 \%$

\begin{tabular}{|c|c|c|c|c|c|c|}
\hline & PA 1 & PA 2 & PA 3 & PA 4 & PA 5 & Total \\
\hline Selaginellaceae & + & + & + & - & + & घ \\
\hline Cyatheaceae/Dicksoniaceae/Dipteridaceae & + & + & + & - & + & च \\
\hline Hydrophytic plants & + & + & it & + & + & घ \\
\hline Cycadales/Bennnetittales/Ginkgoales & 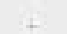 & $\Delta$ & + & 1 & + & च \\
\hline Araucariaceae & I & + & + & - & + & $\bar{a}$ \\
\hline Spheripollenites & t & - & - & - & + & a \\
\hline Cheirolepidiaceae & - & + & 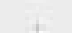 & - & 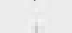 & घ \\
\hline Pinaceae + Podocarpaceae & + & + & + & $\Delta$ & + & घ \\
\hline Pteridospermophyta &. & - & I. & - &. & घ \\
\hline
\end{tabular}

(Figs. 3-4). The levels of this group lie in an intermediate position on the first axis of the second CA. Although the abundance of Spheripollenites is maintained at the level seen in PA3, and in fact remains dominant, there is a considerable increase in the presence of Cheirolepidiaceae (Figs. 7-8). All the taxa groups are present in this PA, which is home to the Toarcian-Aalenian boundary, and all reach their maximum abundance except for Cycadales/Bennnetittales/ Ginkgoales (Table 2). Some 70\% of all bisaccate Coniferophyta miospores were found in this PA. Aquatic palynomorphs become less common. A very small increase in other pollen grains occurs, mainly undetermined bisaccate pollen grains. The species Micrhystridium wattonensis is only recorded in PA4. This assemblage shows the last occurrences of Anapiculatisporites sp., Cardioangulina sp. and Tuberositriletes sp. in the Buckmani Subzone, as well as those of Alisporites sp., Classopollis classoides, Densoisporites velatus, Tasmanites sp. and Todisporites minor in the Opalinum Subzone.

\subsubsection{Palynological assemblage 5}

Palynological assemblage 5 (PA5) lies in the Comptum Subzone and includes levels FZ113 to FZ166 (Fig. 4). This assemblage shows poorly preserved palynomorphs and is characterised by very high percentages of S. psilatus (over $95 \%$ in most levels). The members of Cheirolepidiaceae are scarce (generally under $2 \%$ ). Thus, all the levels of this PA lie at the negative extreme of the first axis of the second CA (Fig. 7). Aquatic palynomorphs become more abundant at levels FZ117, FZ123 and FZ166 (Fig. 5). PA5 is the only assemblage with the acritarch Baltisphaeridium cf. micropunctatum (Plate I, Fig. 5). Spores are at their lowest diversity in the succession with only 10 species represented.

The poor preservation of the microfossils (see also Herrero and Canales, 1997; Perilli, 1999) and general impoverishment of assemblage PAS could be due to diagenetic action of the marly limestones and limestones. Indeed, a change from marly to limestone facies occurs in the Comptum Subzone (Figs. 1B, 4). Traverse (2007) indicates that alkaline environments are not the most suitable for the preservation of palynomorphs. The very scarce presence of palynomorphs other than $S$. psilatus in PAS meant their percentage representations could not be reliably calculated (Fig. 5).

\section{Discussion}

\subsection{Biostratigraphic features}

The inferred assemblages from the Fuentelsaz succession show temporally long-ranging palynomorphs according to the stratigraphic ranges reported in previous research (Wall, 1965; Döring, 1965; Filatoff, 1975; Schuurman, 1977; van Erve, 1977; Boutet, 1981; Davies, 1985; Lund and Pedersen, 1985; Guy-Ohlson, 1986; Srivastava, 1987; Guy-Ohlson, 1990; Rauscher and Schmitt, 1990; Dybkjaer, 1991; Batten and Koppelhus, 1996; Bucefalo-Palliani, 1997; van de Schootbrugge et al., 2005; Peyrot et al., 2007a). The species Araucariacites australis, Cibotiumspora jurienensis, Classopollis classoides, C. torosus, Circumpolles gen. et sp. indet., Cyathidites australis (Plate II, Fig. 3), Micrhystridium lymensis (Plate I, Fig. 2), Perinopollenites elatoides, Retitriletes clavatoides, Spheripollenites psilatus (Plate II, Fig. 6), Uvaesporites argenteaeformis and Vitreisporites pallidus (Plate II, Fig. 7) seem to have existed from the Triassic to the Cretaceous. Other species also appear to have existed until the Cretaceous, e.g., Dictyophyllidites harrisii (Plate I, Fig. 4), Cyathidites minor, Densoisporites velatus and Ischyosporites variegatus (Plate I, Fig. 6) which first appeared in the Hettangian, Todisporites minor which first appeared in the Pliensbachian, and Callialasporites turbatus (Plate II, Fig. 5), Chlamydophorella sp. (Plate I, Fig. 3) and Leptolepidites macroverrucosus (Plate I, Fig. 8) which first appeared in the Toarcian (Fig. 9).

A Toarcian-Aalenian age for the palynological assemblages of Fuentelsaz (Fig. 9) is indicated by (i) a first group of taxa including Kraeuselisportes reissingeri and Trachysporites fuscus, the temporal ranges of which begin in the Upper Triassic and end in the Aalenian (Batten and Koppelhus, 1996), and (ii) a second group composed of Callialasporites minus, C. turbatus, Chlamydophorella sp., Ischyosporites pseudoreticulatus and Leptolepidites macroverrucosus, which first appears in the Toarcian (Boutet, 1981; Davies, 1985; Batten and Koppelhus, 1996).

The biostratigraphic ranges of the acritarchs Micrhystridium wattonensis, M. intromittum (Plate I, Fig. 7) and Baltisphaeridium cf. micropunctatum (Plate I, Fig. 5), and those of Cymathiosphaera cf. pachytheca (Plate I, Fig. 1) are scarcely known outside the Lower Jurassic (Eisenack, 1957; Wall, 1965; van Erve, 1977; van de Schootbrugge et al., 2005). The occurrence of four species in the Aalenian increases their record in the Jurassic.

\footnotetext{
Plate I. Aquatic palynomorph and trilete spore types of the Toarcian and Aalenian of the Fuentelsaz Section:

Cymathiosphaera cf. pachyhec Eisenack 1957, level FZ63, assemblage PA2, base of Aalensis Subzone, late Toarcian; Micrhystridium lymensis Wall 1965, level F2107, assemblage PA4, base of Opalinum Subzone, lowermost Aalenian; Chiamydophorella sp., level F263, assemblage PA2, base of Aalensis Subzone, l.ate Toarcian:

Dictyophyllidites harisii Couper 1958, level FZ15, assemblage PA1, top of Insigne Subzone, Upper Toarcian;

Baitisphaeridium cf. micropunctatum Wall 1965, level FZ156, assemblage PA5, Comptum Subzone, Early Aalenian;

Ischyosporites variegatus (Couper, 1958) Schulz 1967, level F297, assemblage PA3, Buckmani Subzone, l.ate Toarcian;

Micrhystridium intromittum Wall 1965, level FZ65, assemblage PA2, Aalensis Subzone, late Toarcian;

Leptolepidites macroverrucosus Schulz 1967, level FZ71, assemblage PA2, Aalensis Subzone, l.ate Toarcian. Bar $=20 \mu \mathrm{m}$.
} 

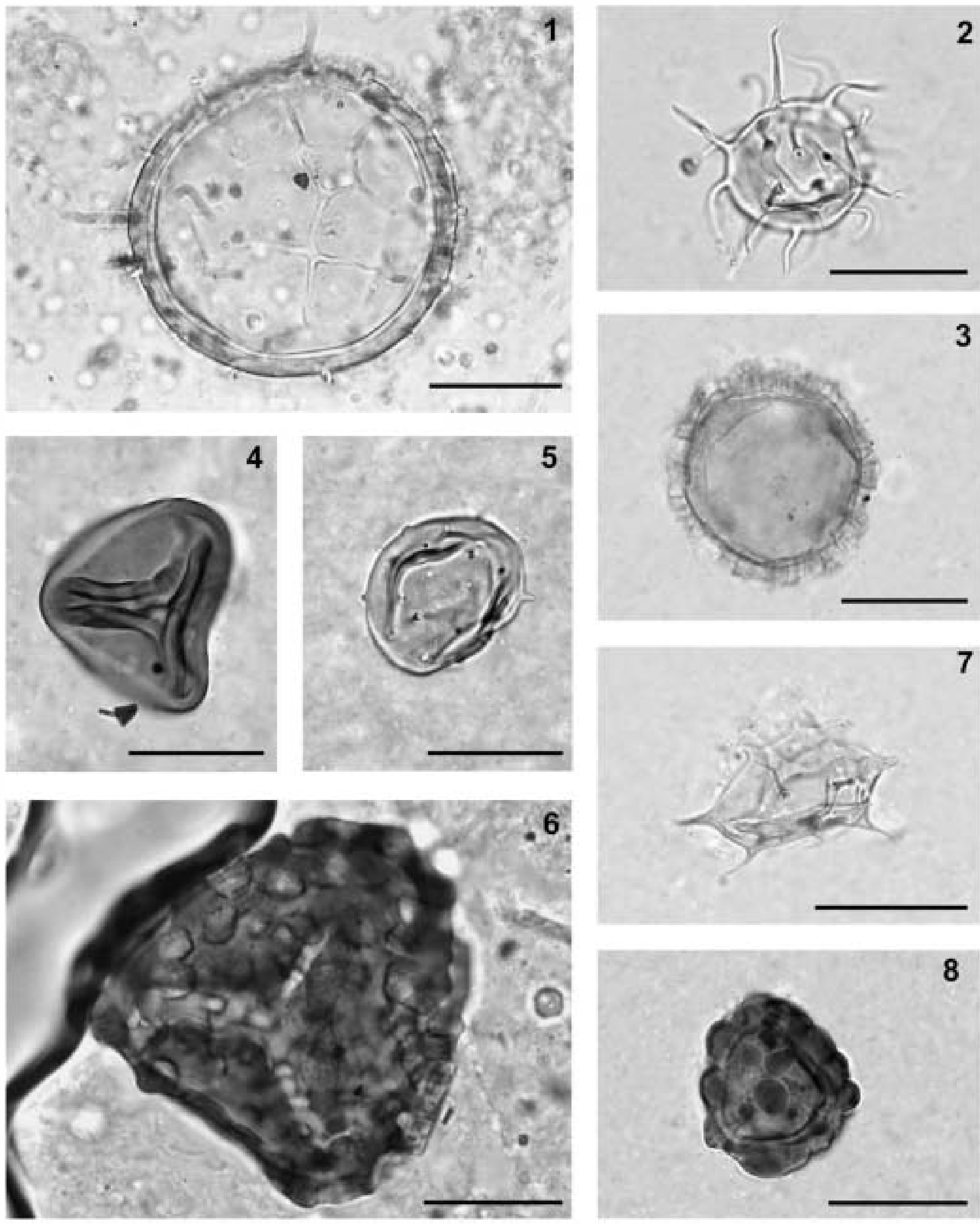

8

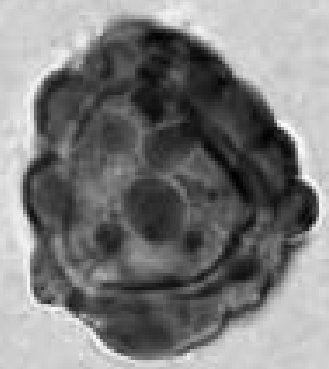


From a qualitative point of view, no important changes in the assemblages can be seen at the Toarcian-Aalenian boundary (the transition from the Buckmani to Opalinum Subzones). Although Micrhystridium wattonensis is recorded for the first time in the final part of the Buckmani Subzone, and Cardioangulina sp. and Tuberositriletes sp. disappeared at this time from the Fuentelsaz Section (Fig. 3), the inferred palynostratigraphic distribution agrees with that reported by Schulzand Mai (1966) and van Erve (1977), who indicate that the palynological assemblages of the earliest Middle Jurassic are very similar to those of the Toarcian, and that it is not yet possible to distinguish between the Toarcian and the lowermost Middle Jurassic by means of palynomorphs.

The inferred assemblages are very different to those included in the Crassitudisporites problematicus Oppel-zone in the Late ToarcianAalenian of the Portuguese sections of Zambujal and Brehna (Davies, 1985). In the latter Oppel-zone, the majority of the taxa identified are not present at Fuentelsaz. In addition, a few of the coincident taxa show different times of appearance and disappearance. For example, Kraeuselisporites resissingeri which is present in the Aalenian of Fuentelsaz, (Fig. 4), has its last occurrence during the Toarcian in Portugal.

\subsection{Palaeoenvironmental features}

The Early and Middle Jurassic epochs were characterised by few differentiated climates. Only five major global climate zones or biomes have been identified by multivariate statistical analysis exploring the foliar morphology/climate relationship (Rees et al., 2000). The lands that today form the Iberian Peninsula were then also in the northern hemisphere, in the north of the subtropical desert belt near to the seasonally dry (winterwet) belt (Fig. 2A). As the presence of evaporites indicates, there is no geological evidence for tropical everwet conditions at latitudes $20-30^{\circ} \mathrm{N}$ in the Westem Tethys area near the Iberian Massif (Hallam, 1984). Rather, a markedly drier climate developed in this area.

The inferred assemblages were obtained in sediments deposited on an extensive marine epeiric carbonate platform that was well connected with the open sea (Cresta et al., 2001). The palaeogeographic maps of Rees et al. (2000), which take into account both floral and lithological data, and those of Gómez et al. (2008), which show palaeogeographic features, indicate the study area corresponded to an epicontinental sea. The marine deposit zone was not far from land where a semiarid desert-like climate prevailed (Fig. 2B).

The microplanktonic assemblages of this ancient sea are rich in calcareous nanoplankton, represented by 46 species (Perilli, 1999). The acanthomorph acritarchs are the next most abundant planktonic microfossil, although these are represented by just five species (Table 1). The proliferation of acanthomorph acritarchs, mainly Micrhystridium, indicates a partly enclosed, shallow, inshore environment (Warrington and Harland, 1975; Courtinat, 2000; Schrank, 2003). According to Wall (1965), the dominance of a single species of acanthomorph acritarch (Micrhystridium lymensis in the studied assemblages) corroborates inshore conditions. The same author also suggests that long-spined acanthomorph acritarchs preferred quiet, low energy conditions.

The finding of a single species of dinoflagellate cyst (Chlamydophorella sp.), although very rare in the Fuentelsaz assemblages (Fig. 3), indicates oligotrophic waters existed during the Toarcian-
Aalenian, since dinoflagellates are associated with mesotrophic conditions (Martin, 1996). An abundance of acritarchs, in contrast, generally indicate stable, stratified, low-nutrient surface waters. In addition, the genus Chlamydophorella includes chorate dinocysts of Tethyan affinity (Bucefalo-Palliani and Riding, 1998) that also indicate an inshore environment.

Considering all the palynomorphs together, the aquatic types appear throughout the succession in low percentages (Fig. 5). Small increases in aquatic palynomorphs are seen after the Cheirolepidiaceae fall to below 10\% in the upper part of the Aalensis Subzone (PA3) and in the lower part of Comptum Subzone (PA5; Fig. 5); this could be related to periods of better communication with the open sea. This is supported by the development of deepening sequences and the sudden arrival of marls in the basin (Gómez and Goy, 2005).

The studied assemblages all contain large amounts of windtransported pollen belonging to xerophilous gymnosperms-plants that produced huge numbers of pollen grains (Fig. 5). In contrast, these same assemblages show low numbers of cryptogamma spores. In general, miospore assemblages are composed of mixtures of pollen of local, regional and extra-regional origin (sensu Jacobson and Bradshaw, 1981; Prentice, 1988). Consequently they are composed of allochthonous elements from a taphonomic point of view.

The best represented miospore in the Fuentelsaz Section is the pollen Spheripollenites psilatus (Fig. 5), which was usually related to the coniferous families Taxaceae, Cupressaceae, Taxodiaceae and Cephalotaxaceae (Couper, 1958; Reyre, 1968). Nevertheless, studies on its exine ultrastructure suggest this relationship cannot be supported (Batten and Dutta, 1997). Abbink (1998) indicates that Spheripollenites are inner bodies (nexine) of coniferous pollen such as Classopollis and Perinopollenites, but these data are not confirmed by ultrastructural studies. Harris (1974) found pollen grains very similar to $S$. psilatus in the bennettitalean species Williamsoniella lignieri. Courtinat (2000) indicates that Spheripollenites belongs to the Cheirolepidiacean-Taxodiacean conifers, inhabitants of swamp environments comparable to mangroves.

Several authors also identified Spheripollenites with algal cysts or metanotrophic bacteria due to it is difficult to differentiate them under transmitted light microscopy (Prauss et al., 1991; BucefaloPalliani and Riding, 2000; Bucefalo-Palliani et al., 2002). However, tetrads of meiospores usually occur in Fuentelsaz as well as pseudoporate grains scarcely ornamented with Ubisch bodies which suggest a relationship with gymnosperms.

Classopollis, the second best represented miospore in the Fuentelsaz Section, was produced by an extinct arboreal or bushy conifer of the family Cheirolepidiaceae. The species of this family were common components of many Toarcian and Aalenian ecosystems, as reflected by their predominance in a large number of palynological assemblages in both hemispheres (see Antonescu, 1973; Herngreen and de Boer, 1974; Filatoff, 1975; van Erve, 1977; Tasch and Lammons, 1978; Candilier et al., 1982; Guy-Ohlson, 1986; Bucefalo-Palliani and Riding, 1998; Martínez et al., 2001; Wang et al., 2005). Traditionally, plants attributed to Cheirolepidiaceae are assumed drought-resistant and adapted to different arid environments, including coastal and saline environments (Alvin, 1982; Watson, 1988; Nguyen Tu et al., 1999; Thévenard et al., 2005). An abundance of 60-90\% of Classopollis indicates arid conditions (Vakhrameev, 1991); these might have developed during the deposition of the levels corresponding to PA1 (Figs. 3, 5). According to Alvin

\footnotetext{
Plate II. Trilete spore and pollen types of the Toarcian and Aalenian of the Fuentelsaz Section:

Leptolepidites sp., level FZ89, assemblage PA3, Buckmani Subzone, Iate Toarcian;

Kracuselisporites reissingeri (Harris 1957) Morbey 1975, level FZ63, assemblage PA2, base of Aalensis Subzone, Iate Toarcian;

Cyathidites australis Couper 1953, level F243, assemblage PA2, base of Mactra Subzone, l.ate Toarcian;

Lycopodiacidites rugulatus (Couper, 1958) Schulz 1967, level F2107, assemblage PA4, base of Opalinum Subzone, lowermost Aalenian;

Callialasporites turbatus (Balme 1957) Schulz 1967, level FZ89, assemblage PA3, Buckmani Subzone, l.ate Toarcian;

Spheripollenites psilatus Couper 1958, level FZ43, assemblage PA2, base of the Mactra Subzone, l.ate Toarcian;

Vitreisporites pallidus (Reissinger 1950) Nilsson 1958, level FZ101, assemblage PA3, Aalensis Subzone, Iate Toarcian. Bar =20 m
} 

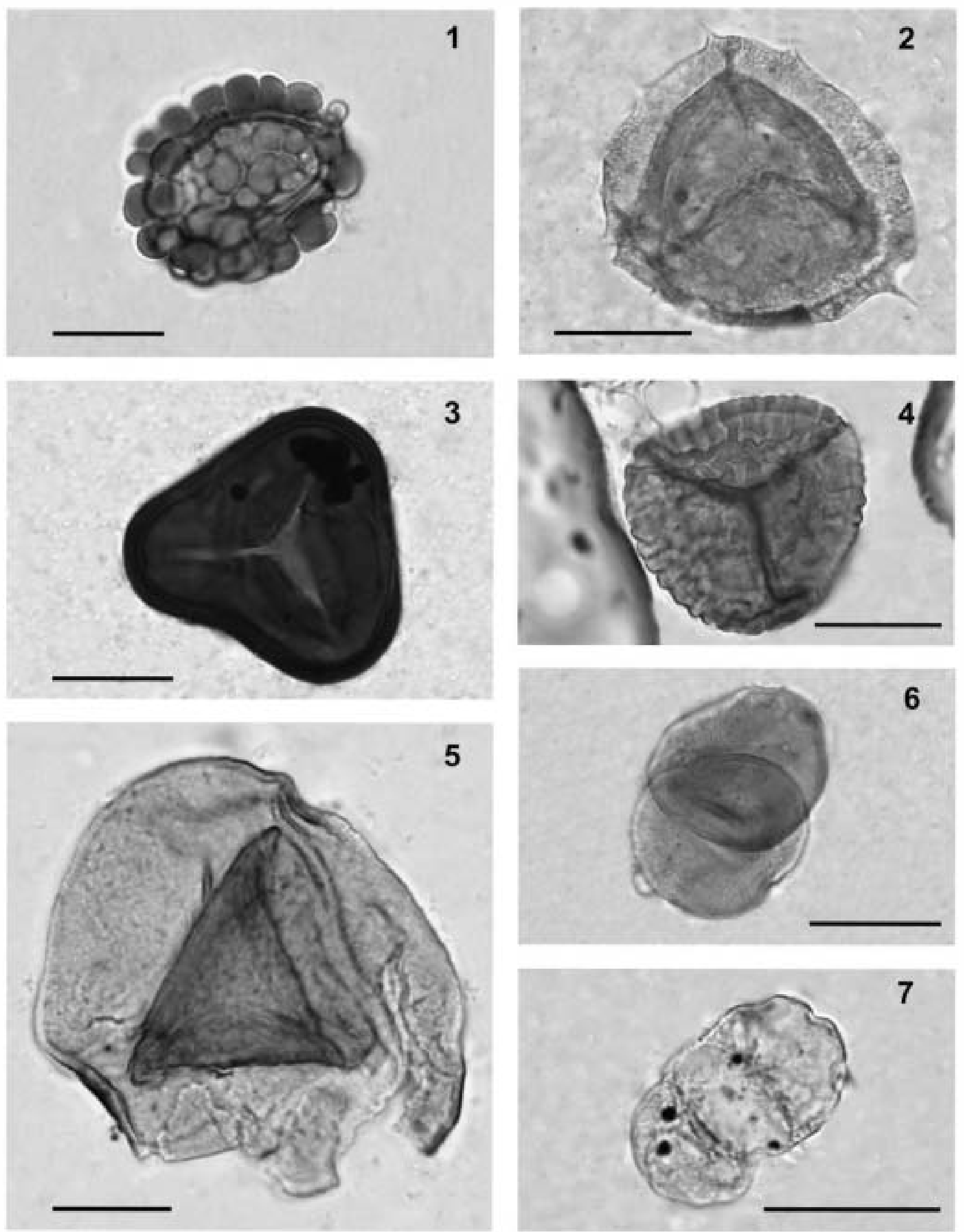


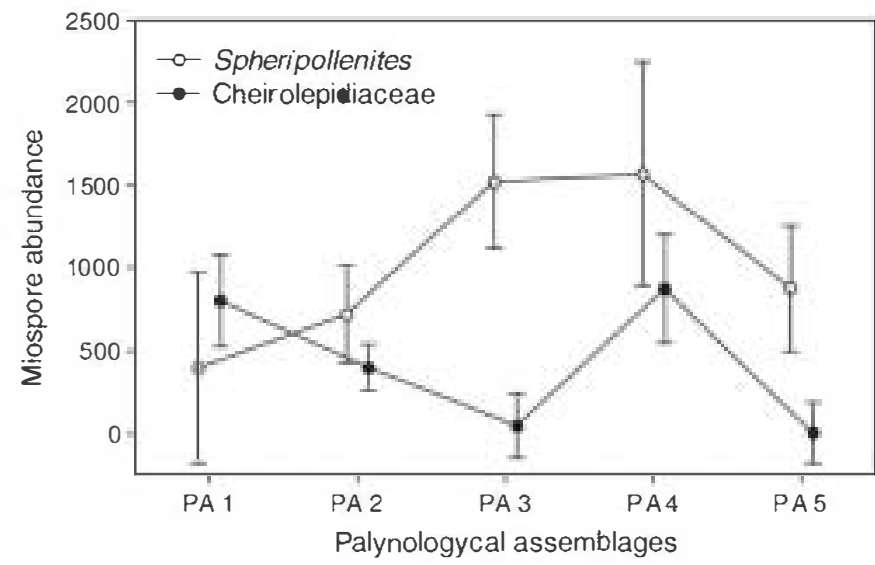

Fig. 8. Change in the mean abundance of Spheripollenites and Cherolepidiaceae the five palynological assemblages (PA). Vertical bars denote the $95 \%$ confidence intervals.

(1982) and Mohr (1989), the occurrence of huge amounts of Spheripollenites together with large numbers of Classopollis indicates a strongly developed annual dry season; this could have been important in the Fuentelsaz area during the deposition of the levels corresponding to PA2 and PA4 (Fig. 5).

The remaining pollen grains in the different levels of the succession are very scarce (Fig. 5) and always show an anemophilous nature. Bisaccate pollen grains of unknown Coniferophyta are always present in small numbers in PA1, PA2 and PA4 (Figs. 3-4). PA2 is also characterised by representatives of Pteridospermophyta and Cycadopites (Fig. 3). The family Araucariaceae is present from level FZ-43 to the top of the succession. This family is better represented in PA3 than in the other assemblages, except for PAS (Figs. 3-4).

The scarcity of heterogeneous groups of other pollen grains (Fig. 5) in the studied assemblages could be due to: (i) their being allochthonous in the assemblages, being produced in continental locations far away the place of fossilization, (ii) by their being less productive and having a lower wind transport capacity than either Spheripollenites and Classopollis (the case of Cycadopites and Araucariacites), or, (iii) given the arid conditions of the region, their being produced by plants that lived in wet places (the case of Perinopollenites and some Pteridospermophyta).

The spores of vascular cryptogamma are present throughout the succession but in small numbers (Fig. 5). Ornamented spores of the species Kraeuselisporites reissingeri and Uvaesporites argenteaeformis, and psilate spores of Cyathidites australis and $C$. minor, are the most conspicuous (Figs. 3-4). Generally, vascular cryptogamma need a humid environment to reproduce. However, some of them adapted to grow under much drier and stressed conditions, especially during the Mesozoic (Abbink, 1998). The first two mentioned species are related to members of the family Selaginellaceae, the representatives of which nowadays occupy a wide range of habitats from rainforests to deserts (Webster, 1992). Due to the general arid conditions that existed in the study zone, it is possible that their sellaginellous producers were adapted to resist dry environments.

The common occurrence of Cyathidites also supports the existence of high-stress environments. Ferns of the families Dicksoniaceae and Dipteridaceae showing noteworthy protection of their sporangia and coriaceous fronds indicative of adaptation to stressful environments, have been recorded at several Mesozoic sites (Diéguez and Meléndez, 2000; Van Konijnenburg-Van Cittert, 2002). In contrast, the spores of Lycophyta (Densoisporites velatus, Leptolepidites spp., Lycopodiacidites rugulatus, Lycopodiumsporites semimuris, Retitriletes spp.) and Pteridophyta (Baculatisporites sp., Ischyosporites spp. and Todisporites minor) indicate plants that required hygrophilous, wet habitats such as coastal swamps or ponds. Possibly, the lack of Sphenophyta spores in the studied assemblages is a reflection of desert-like conditions since this group is always associated with pre-humid freshwater-containing places.

Spores are relatively well represented in PA3, coinciding with the greatest presence of Araucariaceae (Fig. 5). This would appear to indicate the presence of more humid environmental conditions. The
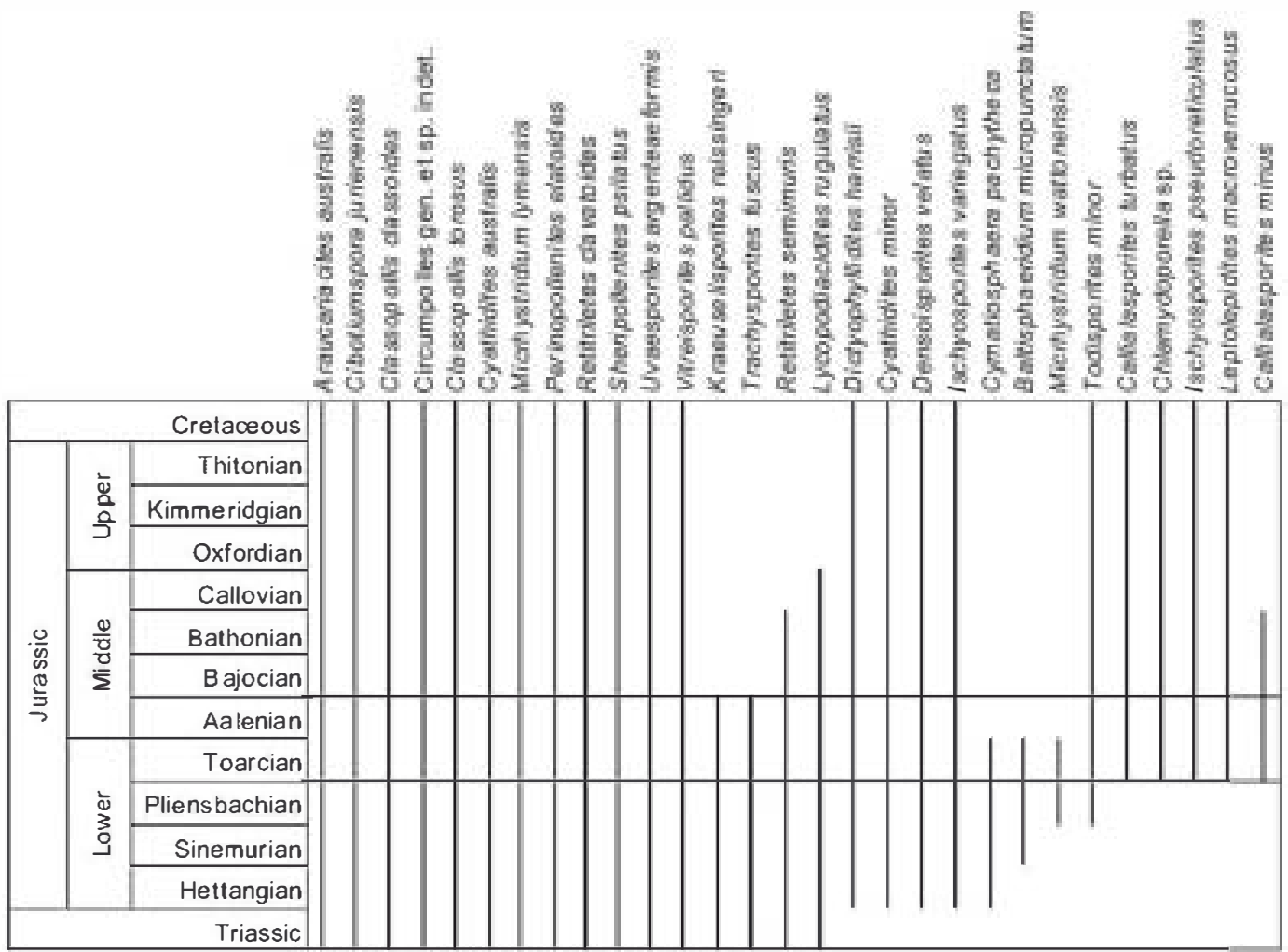

Fig. 9. Composite range chart showing selected species of biostratigraphic interest identified in the Toarcian and Aalenian sediments of the Fuentelsaz Section. 
scant presence of spores in PA1, PA2 and PA4 coincides with high percentages of Cheirolepidiaceae (Figs. 3,5), except in level FZ43. This level is dominated by $S$. psilatus; the remaining palynomorphs are poorly preserved and in very small numbers.

In general, the data provided by the present miospore study agree with the composition of the Early and Middle Jurassic floras of the Eurosinian region inferred from the study of plant mega- and microremains. These floras were mainly composed of horsetails, ferns, seed ferns, cycads, Bennettitales, cycadophytes of unestablished systematics, Ginkgoales and conifers (Vakhrameev, 1991).

The vegetation of the Fuentelsaz area during the Lower-Middle Jurassic transition may have been mainly represented by gymnosperms growing in a subtropical arid climate. These gymnosperms possibly formed scrub dominated by Cheirolepidiaceae, and coastal forest belts where the unknown producer of $S$. psilatus grew. Here, other gymnosperms such as Araucariaceae would also have been able to grow. Sellaginellous cryptogams and ferns adapted to dry environments would have developed in the undergrowth of these formations. This would appear to be confirmed by the results of the second CA (Fig. 7). Several places with wetter habitats, perhaps swamps or ponds, would have allowed the development of other lycophytic and fern communities within this generally arid context, but without such a clear marine influence as the taxa groups might suggest, appearing as they do with negative values on the first axis of the second $C A$.

The little information that exists on Southern European Liassic megaflora seems to corroborate the existence of arid conditions in the study zone. The Toarcian megaflora of Budoshi in Chernogoria (Montenegro) seems to represent an island flora; a humid belt would have existed along the shore, while coniferous vegetation would have prevailed in the drier interior (Pantić, 1981).

The dominance of $S$. psilatus begins in PA2, and even increases in PA3 and PA5 (Fig. 5). This pollen increases the number of grains per level from the top of the Mactra Subzone in PA2. Possibly, the gymnosperm that produced Spheripollenites lived alongside conifers related to Classopollis, the former dominating when the climate was more humid. Increases in humidity may have been related to the development of better communications with the open sea. Consequently, when $S$. psilatus begins to appear in large numbers in the assemblages, spores and other types of pollen grains become more diverse. This can be seen in PA2, in which the diversity of miospores increases (Fig. 3), and very clearly in PA3, in which Cheirolepidiaceae is represented in low numbers (Fig. 5). PA3 also shows conspicuous amounts of spores and Araucariacean pollen.

The boundary between the Toarcian and the Aalenian in PA4 is characterised by an increase in the presence of Cheirolepidiaceae and a reduction in S. psilatus (Fig. 5). A conspicuous reduction in spore and pollen grain diversity is also seen, indicating an increase in aridity during this period. Although PAS contains members of the Cheirolepidiaceae in low numbers, poor preservation prevents the making of any inferences regarding vegetation patterns (Figs. 4, 5).

In general, the importance of the producers of Spheripollenites and Classopollis in terrestrial ecosystems may have alternated in the Late Toarcian and Early Aalenian in the Fuentelsaz area, depending on regional climatic or/and environmental factors, which in turn depended of the communication of the basin with the open sea.

\subsection{Comparison of assemblages}

Generally, Jurassic palynological assemblages contain species with a more or less cosmopolitan distribution, facilitating the comparison of widely separated parts of the world (Visscher et al., 1980). This generalisation holds for the assemblages of Fuentelsaz. However, despite the taphonomic bias they show, they have compositions different to those of their contemporaneous counterparts in other areas of Europe. Generally, Classopollis dominates European Toarcian-
Aalenian assemblages which usually also contain dinoflagellate cysts (Antonescu, 1973; Candilier et al., 1982; Davies, 1985; Guy-Ohlson and Malmquist, 1985; Guy-Ohlson, 1986; Bucefalo-Palliani and Riding, 1998, 2000; Feist-Burkhardt and Pross, 2010). Other palynomorphs such as spores and bisaccate and/or inaperturate pollen grains characterise the assemblages of this interval in some parts of Europe (Couper, 1958; Danzé and Laveine, 1963; Schulz, 1967; Herngreen and de Boer, 1974; Riding, 1984; Hoelstad, 1985; Bucefalo-Palliani and Riding, 1998). The reasons for the different composition seen in the Fuentelsaz succession may be related to the palaeogeography of the western margin of the peri-Tethyan basin, since this area comprised a system of shallow platforms that developed on the progressively submerging Iberian block (Gómez and Goy, 2005). However, it could also be due to the latitude of this basin, which would have facilitated the emerged areas adopting a more subtropical desert nature (Ziegler et al., 1993).

The Toarcian Age witnessed a transgression in Western and Southern Europe. Therefore, continental deposits from this time are virtually non-existent in these territories (Vakhrameev, 1991). This may be one of the reasons for the lack of palaeobotanical data available, emphasising the importance of the study of Fuentelsaz.

As mentioned above, the assemblages of the Toarcian-Aalenian interval in Fuentelsaz are dominated by Spheripollenites psilatus or/ and Classopollis. Spheripollenites is important in the assemblages of Northern Europe from the Upper lias onward (Dybkjaer, 1991). This might be related to the anoxic event that happened in the early Toarcian (Gómez et al., 2008). This genus commonly appears in the Early Toarcian of Jameson Land in eastern Greenland (assemblage B) (Lund and Pedersen, 1985) and the Fjerritslev Formation (Spheripollenites-Leptolepidites zone, Danish sub-basin) (Dyblkjaer, 1991), and in the Toarcian of Lincolnshire and Yorkshire (England) (Wall, 1965), of Anholt Island (Norway) (Seidenkrantz et al., 1993), of Øresund (Spheripollenites-Leptolepidites zone, Denmark) (Koppelhus and Batten, 1996), and in the Aalenian of Scania (Sweden) (GuyOhlson, 1986). However, these assemblages generally show higher numbers and more diverse spores and pollen grains than found at Fuentelsaz. This may well be due to the influence of latitude and the temperate and wetter climates of the more northerly regions. Upper Liassic assemblages dominated by Spheripollenites, various inaperturate pollen types and Classopollis have been recorded in Algeria and Tunisia (Reyre, 1967, 1973). These assemblages which show an increase in the number of spores from the Dogger onwards, reveal forest and diverse plant communities very different to those of Fuentelsaz.

The genus Classopollis was a pollen type of worldwide distribution during the Lower-Middle Jurassic (Srivastava, 1966; Filatoff, 1975; Bujak and Williams, 1977; Tasch and lammons, 1978; Vakhrameev, 1991; Liu, 2000; Martínez et al., 2001; Wang et al., 2005). In Southern Europe it dominates the Toarcian of the Vicentinian Alps (Italy) (van Erve, 1977), the upper Toarcian of Zambujal (Portugal) (Davies, 1985), the Toarcian-Aalenian of Cristian (Romania) (Antonescu, 1973), and the Toarcian-Aalenian of Grésigne-Sud Quercy (France) (Boutet, 1981). Generally, these palynofloras of France and Portugal show greater numbers of spores and dinoflagellate cysts. However, the percentages of Spheripollenites, and those of Classopollis, psilate spores, Uvaesporites argenteaeformis and acritarchs recorded in zones 6 and 7 of Grésigne-Sud Quercy by Boutet (1981), are similar to those seen in the assemblages of Fuentelsaz.

Filatoff (1975) proposed correlations be sought between the Jurassic Australian basins and other well-defined Jurassic basins around the world, and for this defined six groups of miospores based on their botanical affinities: (I) Classopollis spp., (II) other small, inaperturate or pseudoporate pollen (Cupressaceae/Taxaceae/Taxodiaceae type), (III) lentoid, commonly cavate pollen (Araucariaceae type), (IV) di- and trisaccate pollen, (V) spindle-shaped, monosulcate pollen or polyplicate pollen, and (VI) spores. Representatives of all 
these six groups are found in the Fuentelsaz Section. The best represented group in the Insigne Subzone is group I, though its importance gradually decreases beyond the uppermost part of this subzone (Fig. 5). The rest of the succession is numerically dominated by miospores of group II or co-dominated by those of I and II (Fig. 5). Group II gradually became more important in the palynofloras of Western Europe at the beginning of the Toarcian, before becoming predominant in the miospore assemblages of the Aalenian. This increase can be seen in the Strangewaysi Subzone of the Lower Toarcian in the Iberian Range (Barrón et al., 1999a). Group III is wellcharacterised in Western Europe from the early Toarcian (Batten and Koppelhus, 1996). Guy-Ohlson (1988) indicates a sudden proliferation of Araucariaceous pollen in the Toarcian, detectable all around the world. However, the representatives of group III at Fuentelsaz are in very low number (as seen in Eastern Europe), while groups IV, V and VI are scantily represented at Fuentelsaz but in a manner similar to that inferred for the Toarcian-Aalenian of Western Europe. The lack of palynological data for southwestern Europe prevents the making of any correlation with the vertical variability diagrams presented by Filatofffor Western and Eastern Europe. The scarcity of groups Ill, IV, V and VI in Fuentelsaz is surely due to a taphonomical bias due to differential transport, and the existence of less diverse plant communities than in more northerly latitudes. If the variation of percentages of groups I and II are considered alone, the Fuentelsaz assemblages can be related to those of both Western and Eastern Europe (see Filatoff, 1975, text-Fig. 9) due to their similar importance in these regions at the Toarcian-Aalenian boundary.

\section{Conclusions}

The palynological study of the Fuentelsaz Section, the GSSP for the base of the Aalenian, led to the identification of 43 palynomorph taxa, most with long stratigraphic ranges, and five successive assemblages characterised by the over-representation of miospores and the scarcity of aquatic palynomorphs. PA1 corresponds to the Insigne Subzone and is characterised by the dominance of Classopollis. PA2 is found in the Pseudoradiosa and Mactra Subzones and in the lower halfofthe Aalensis Subzone, and shows Classopollis and Spheripollenites to alternate in importance. PA3 lies in the upper half of the Aalensis Subzone and most of the Buckmani Subzone; it shows high percentages of Spheripollenites and a conspicuous presence of spores and araucariaceous pollen grains. PA4 is represented at the boundary between the Toarcian (Buckmani Subzone) and the Aalenian (Opalinum Subzone), where a new increase in Classopollis is seen. The disappearance from PA4 of Alisporites sp., Classopollis classoides, Densoisporites velatus, Tasmanites sp., Todisporites minor and Tuberositriletes sp., does not indicate a great change in the ecological or sedimentological conditions during the Toarcian-Aalenian transition. In fact, these taxa are of little biostratigraphic value. The species Micrhystridium wattonensis is only recorded in this assemblage. PAS is found in the Comptum Subzone and contains poorly preserved palynomorphs, although it shows high percentages of Spheripollenites. This may be related to alkaline diagenetic conditions produced in the predominantly carbonatic sedimentation environment. PAS is the only assemblage to show the acritarch Baltisphaeridium cf: micropunctatum.

The conspicuous presence of the acritarch Micrhystridium lymensis indicates the area was probably an inshore environment with shallow water and low energy conditions. On the land, subtropical plant communities characterised by gymnosperms and vascular cryptogams adapted to arid conditions. In the driest periods a scrub of Cheirolepidiaceae probably dominated the landscape.

Periods coinciding with the development of deep sequences and the arrival of marls in the basin were times when the communication with the open sea was better. During such times, the climatic conditions were less arid and communities with gymnosperms that produced Spheripollenites were probably common along the shores.
The periods dominated by Spheripollenites may have been richer in cryptogams and conifers (such as Araucariaceae) than in Cheirolepidiaceous times.

In general, the five assemblages identified show similarities to zones 6 and 7 of the Toarcian and Aalenian of Grésigne-Sud Quercy, France.

\section{Acknowledgements}

This research work was financed by projects CGL2005-0474/BTE and CGL2008-03112/BTE from the Spanish Ministry of Science and Innovation, and 910431 from the UCM-CCMM. We wish to thank Peggy Tan (Journal Manager) as well as the anonymous referees who provided useful criticisms and valuable suggestions. We also thank Javier Castrillo and Daniel Peyrot for their help and kindness. This paper is a contribution to the International Geological Correlation Program Project 467/506 (Triassic/Jurassic times). Adrian Burton and Otto Kälin are thanked for their assistance with the English manuscript.

\section{References}

Abbink, O.A., 1998. Palynological investigations in the Jurassic of the North Sea region. Iab. Palaeobot. Palynol. Contrib. Ser. 8, 1-191.

Adloff, M.C., Doubinguer, J., 1978. Associations palynologiques du Trias et du lias Inférieur de l'Ouest de I'Europe (l.uxembourg, France, Portugal). Palinología núm. extraord. 1, 21-25.

Adloff, M.C., Doubinguer, J., Palain, C., 1974. Contribution à la Palynologie du Trias et du Lias inférieur de Portugal, "Grès de Silves" du Nord Tage. Comm. Serv. Geol. Portugal 58, 91-144.

Alvin, K.L., 1982. Cheirolepidiaceae: biology, structure and palaeoecology. Rev. Palaeobot. Palynol 37, 71-98.

Antonescu, E., 1973. Quelques données sur la Palynologie du lias sous faciès de Gresten de Roumanie. In: Chlonova, A. (Ed.), Palynology of the Mesophyte. Proc. 3rd Int. Palynol. Conf. Novosibirsk, pp. 53-57.

Aurell, M., Robles, S., Badenas, B., Rosales, I., Quesada, S., Melendez, G., Garcia-Ramos, J.C., 2003. Transgressive-regressive cycles and Jurassic palaeogeography of northeast Iberia. Sed. Geol. 162, 239-271.

Balme, B.E., 1995. Fossil in situ spores and pollen grains: an annotated catalogue. Rev Palaeobot. Palynol. 87, 81-323.

Barrón, E., Azerédo, A.C, 2003. Palynology of the Jurassic (Callovian-Oxfordian) succession from Pedrógào (l.usitanian Basin, Portugal). Palaeoecological and palaeobiogeographical aspects. N. Jb. Geol. Palàontol. Abh. 227 (2), 259-286.

Barrón, E., Comas-Rengifo, M.J., Trincâo, P., 1999a. Estudio palinológico del tránsito Pliensbachiense/Toarciense en la Rambla del Salto (Sierra Palomera, Teruel, España). Cuad. Geol. Ibérica 25, 169-185.

Barrón, E., Gómez, J.J., Goy, A., 1999b. Dataciones con palinomorfos en los materiales del tránsito Triásico-Jurásico de Poza de la Sal (Burgos). Publ. Sem. Paleontol. Zaragoza $5(1), 46-55$.

Barrón, E., Gómez, J.J., Goy, A., Pieren, A.P., 2006. The Triassic-Jurassic boundary in Asturias (northern Spain): palynological characterisation and facies. Rev. Palaeobot. Palynol. 138, 187-208.

Batten, D.J., 1999. Small palynomorphs. In: Jones, T.P., Rowe, N.P. (Eds.), Fossil plants and spores: modern techniques. Geol. Soc. london, UK, pp. 15-19.

Batten, D.J., Dutta, R.J., 1997. Ultrastructure of exine of gymnospermous pollen grains from Jurassic and basal Cretaceous deposits in Northwest Europe and implications for botanical relationships. Rev. Palaeobot. Palynol. 99, 25-54.

Batten, D.J., Koppelhus, E.B., 1996. Chapter 20D. Biostratigraphic significance of uppermost Triassic and Jurassic miospores in Northwest Europe. In: Jansonius, J. McGregor, D.C. (Eds.), Palynology: Principles and Applications: Am. Assoc. Stratigr Palynol. Found, vol. 2, pp. 795-806.

Benzécri, J.-P., 1973. L'analyse des Données, vol. 2. l'analyse des correspondances, Dunod, Paris. 632pp.

Boland, D.C, 1986. Upper Jurassic (Portlandian) sedimentology and palynofacies of Cabo Espichel, Portugal. M. Sc. thesis. Univ. Newfoundland, Canada. 261pp.

Boulter, M.C., Windle, T., 1993. A reconstruction of some Middle Jurassic vegetation in Northern Europe. Spec. Pap. Palaeontol. 49, 125-138.

Boutet, C., 1981. Étude palynoplanctologique du Trias et du Jurassique Inférieur et Moyen de Grésigne-Sud Quercy. Ph.D. thesis. Univ. Paul Sabatier, Toulouse, France. 161 pp.

Briche, P., Danzé-Corsin, P., l.aveine, J.P., 1963. Flore infraliasique du Boulonnais (Macro- et Microflore). Soc. Géol. Nord. Mém. 13, 7-143.

Bucefalo-Palliani, R., 1997. Toarcian sporomorph assemblages from the UmbriaMarche Basin, Central Italy. Palynology 21, 105-121.

Bucefalo-Palliani, R., Riding, J.B., 1998. The Palynology of the Toarcian-Aalenian transition in the Wittnau borehole (Oberrhein, Southwest Germany). N. Jb. Geol. Palàontol. Abh. 210 (2), 143-184.

Bucefalo-Palliani, R, Riding, J.B., 2000. A palynological investigation of lower and lowermost Middle Jurassic strata (Sinemurian to Aalenian) from North Yorkshire. Proc. Yorks. Geol. Soc. 53, 1-16.

Bucefalo-Palliani, R., Mattioli, E., Riding, J.B., 2002. The response of marine phytoplankton and sedimentary organic matter to the early Toarcian (Iower Jurassic) oceanic anoxic event in northern England. Mar. Micropaleontol. 46, 223-245. 
Bujak, J., Williams, G.L., 1977. Jurassic palynostratigraphy of offshore Eastern Canada. In: Swain, F.M. (Ed.), Stratigraphic Micropalaeontology of Atlantic Basin and borderlands. Dev. Palaeontol. Stratigr. 6, 321-339.

Candilier, A.M., Coquel, R., Decommer, H., 1982. Étude palynologique du lias dans le Boulonnais (Nord de la France). Rev. Micropaléontol. 25 (1), 17-25.

Clarke,R.F.A.,Verdier, J.-P., 1967.An investigation of microplankton assemblages from the Chalk of the Isle ofWight, England. Verh. K. Ned. Akad. Wet., Afd. Natuurkd, Reeks 24 (3), 1-96.

Comas-Rengifo, M.J., Goy, A., 1983. Macropaleontología. In: Portero, J.M., Gutiérrez, M. Aguilar, M.J., l.eal, M.C., Giner, J. (eds.), Explicación de la Hoja no. 464. Mapa Geológico de España. Escala 1:50.000, IGME, Madrid, Spain. 74pp.

Couper, R.A., 1958. British Mesozoic microspores and pollen grains. A systematic and stratigraphic study. Palaeontogr. Abt. B 103, 75-179.

Courtinat, B., 2000. Review of the dinoflagellate cyst Subtilisphaera ? inffect (Drugg 1978) Bujak \& Davies, 1983 and S. paeminos (Drugg, 1978) Bu jak \& Davies, 1983. J. Micropalaeontol. 19, 165-175.

Cresta, S., Goy, A., Ureta, S., Arias, C., Barrón, E., Bernad, J., Canales, M.L., García-Joral, F. Garća-Romero, E., Gialanella,P.R., Gómez, J.J., González,J.A., Herrero, C., Martínez, G. Osete, M.L., Perilli, N., Villalaín,J.J., 2001. The Global Boundary Stratotype Section and Point (GSSP) of the Toarcian-Aalenian Boundary (Iower-Middle Jurassic). Episodes $24,166-175$.

Danzé, J., l.aveine,J.P., 1963. Étude palynologique d'une argile provenant de la limite lias Dogger, dans un sondage à Boulogne-sur-Mer. Ann. Soc. Geol. Nord 83, 79-90.

Davies, E.H., 1985. The miospore and dinoflagellate cyst Oppel-Zonation of the lias of Portugal. Palynology 9, 105-132.

de Jersey, N.J., 1960. Jurassic spores and pollen grains from the Rosewood coalfield Geol. Surv. Queensland Publ. 294, 1-14.

Dera, G., Pellenard, P., Neige, P., Deconinck, J.F., Pucéat, E., Dommergues, J.L., 2009. Distribution of clay minerals in Early Jurassic Peritethyan seas: palaeoclimatic significance inferred from multiproxy comparisons. Palaeogeogr. Palaeoclimatol Palaeoecol. 271, 39-51.

Diéguez, C, Meléndez, N., 2000. Early Cretaceous ferns from lacustrine limestones at l.as Hoyas, Cuenca province, Spain. Palaeontology 43 (6), 1113-1141.

Döring, H., 1965. Die sporenpaläontologische Gliederung des Wealden in Westmecklenburg (Struktur werle). Geologie 47, 1-118.

Doubinguer, J., Adloff, M., Palain, C, 1970. Nouvelles precisions stratigraphiques sur la série de base du Mesozoïque portugais. CR Acad. Sci. Paris 270, 1700-1772.

Dybkjaer, K., 1991. Palynological zonation and palynofacies investigation of the Fjerritslev Formation (lower Jurassic-basal Middle Jurassic) in the Danish Subbasin. Dan. Geol. Unders. ser A 30, 1-150.

Eisenack, A., 1957. Mikrofossilien in organischer Substanz aus dem lias Schwabens (Siiddeutschland). N. Jb. Geol. Paläontol. Abh. 105, 239-249.

Fauconnier, D., 1997. Kystes de dinoflagellés des domaines Nord-Ouest Européen et Sud Téthysien. In: Carico, E., Hantzpergue, P. (Eds.), Biostratigraphie du Jurassique Ouest-Européen et Méditerranée: Bull. Centre Rech. Explor.-Prod. Elf-Aquitaine, 17, 225-241.

Fauconnier, D., Masure, E., 2004. les dinoflagellés fossile. In: BRGM (Ed.), Guide pratique de détermination kystes chorates, proximochorates et proximates à archéopyle apical. Collection Sci, Orleans, p. 602

Feist-Burkhardt, S., Pross, J., 2010. Dinoflagellate cyst biostratigraphy of the Opalinuston Formation (Middle Jurassic) in the Aalenian type area in southwest Germany and north Switzerland. lethaia 43, 10-31.

Fenton, J.P.G., Fisher, M.J., 1978. Regional distribution of marine microplankton in the Bajocian and Bathonian of northwest Europe. Palinología no. extraord. 1, 233-243.

Filatoff, J., 1975. Jurassic palynology of the Perth Basin, Western Australia. Palaeontogr Abt. B 154, 1-133.

García-Frank, A., Ureta, S., Mas, R., 2008. Aalenian pulses of tectonic activity in the Iberian Basin, Spain. Sed. Geol. 209, 15-35.

García-Joral, F., Goy, A., 1994. The associations of brachiopods from the ToarcianAalenian Transition in the Fuentelsaz section (Iberian Range, Spain). Geobios M.S $17,223-228$.

Gómez, J.J., Comas-Rengifo, M.J., Goy, A., 2003. L.as Unidades litoestratigráficas del Jurásico Inferior de las Cordilleras Ibérica y Costeras Catalanas. Rev. Soc. Geol. Esp. $16,227-238$

Gómez, J.J., Goy, A., 2005. l.ate Triassic and Early Jurassic palaeogeographic evolution and depositional cycles of the Western Tethys Iberian platform system (Eastern Spain). Palaeogeogr. Palaeoclimatol. Palaeoecol. 222, 77-94.

Gómez, J.J., Goy, A., Barrón, E., 2007. Events around the Triassic-Jurassic boundary in northern and eastern Spain: a review. Palaeogeogr. Palaeoclimatol. Palaeoecol. 244 89-110.

Gómez, J.J., Goy, A., Canales, M.L., 2008. Seawater temperature and carbon isotope variations in belemnites linked to mass extinction during the Toarcian (Early Jurassic) in Central and Northern Spain. Comparison with other European sections. Palaeogeogr. Palaeoclimatol. Palaeoecol. 258, 28-58.

Goy, A., Ureta, M.S., 1987. Ieioceratinae (Ammonitina) del Aaleniense inferior de Fuentelsaz (Cordillera Ibérica, España). Boll. Soc. Paleontol. Ital. 25, 213-236.

Goy, A., Ureta, M.S., 1991. The lower boundary of the Aalenian in the Fuentelsaz section (Iberian Range, Spain). In: Morton, N. (Ed.), Conference on Aalenian and Bajocian Stratigraphy, Isle of Skye, Birkbeck College. Univ. I.ondon, UK, pp. 33-47.

Goy, A., Gómez, J.J., Yébenes, A., 1976. El Jurásico de la Rama Castellana de la Cordillera Ibérica (mitad Norte). I Unidades litoestratigráficas. Estud. Geol. 32, 391-423.

Goy, A., Ureta, S., Arias, C., Canales, M.L., García Joral, F., Herrero, C., Martínez, G., Perilli, N., 1994. The Fuentelsaz section (Iberian Range, Spain), a possible stratotype for the basis of the Aalenian stage. Misc. Serv. Geol. Naz. 5, 1-31.

Goy, A., Ureta, S., Arias, C., Bernad, J., Barrón, E., Canales, M.L., García Joral, F., Gialanella, P.R., Gómez, J.J., Herrero, C., Martínez, G., Osete, M.L., Perilli, N., Villalaín, J.J., 1996
The Toarcian/Aalenian transition in Fuentelsaz section. In: Ureta, S. (Ed.), 1st Toarcian and 4th Aalenian Working Groups Meeting. Fieldtrip Iberian Range GuideBook. Univ. Complutense Madrid, Spain, pp. 49-77.

Goy, A., Ureta, S., Arias, C., Barrón, E., Bernad,J., Canales, M.L., García Joral, F., Gialanella, P.R., Gómez, J.J., Herrero, C., Martínez, G., Osete, M.L., Perilli, N., Villalaín, J.J., 1999. The Fuentelsaz Section (Guadalajara, Iberian Range, Spain): a possible global geosite. In: Baretino, D., Vallejo, M., Gallego, E. (Eds.), Towards the Balanced Management and Conservation of the Geological Heritage in the New Millenium: Soc. Geol. Esp., Madrid, Spain, pp. 228-233.

Guy, D.J.E., 1971. Palynological investigations in the Middle Jurassic of the Vilhelmsfält boring, Southern Sweden. Publ. Inst. Mineral. Paleontol. Quatern. Geol. 168, 1-104.

Guy-Ohlson, D., 1982. Biostratigraphy of the Iower Jurassic-Cretaceous unconformity at Kullemölla, Southern Sweden. Sver. Geol. Unders. Ser. C 52, 1-45.

Guy-Ohlson, D., 1986. Jurassic Palynology of the Vilhelmsfalt bore n 1, Scania, Sweden, Toarcian-Aalenian. Section of Palaeobotany. Swed. Mus. Nat. Hist., Stockholm, p. 127.

Guy-Ohlson, D., 1988. Toarcian palynostratigraphical correlations within and between different biogeographical provinces. 2nd Internat. Symp. Jurassic Stratigr. lisboa, pp. $807-820$.

Guy-Ohlson, D., 1990. Pliensbachian palynology of the Karindal bore no.1, north-west Scania, Sweden. Rev. Palaeobot. Palynol. 65, 217-228.

Guy-Ohlson, D., Malmquist, E., 1985. Iower Jurassic biostratigraphy of the Oppegard Bore No. 1, NW Scania, Sweden. Sver. Geol. Unders. 40, 1-27.

Hallam, A., 1984. Continental humid and arid zones during the Jurassic and Cretaceous. Palaeogeogr. Palaeoclimatol. Palaeoecol. 47, 195-223.

Harris, T.M., 1974. Williamsonie lilignieri: its pollen and the compression of spherical pollen grains. Palaeontology 17, 125-148.

Herkat, M., 2007. Application of correspondence analysis to palaeobathymetric reconstruction of Cenomanian and Turonian (Cretaceous) rocks of Eastern Algeria. Palaeogeogr. Palaeoclimatol. Palaeoecol. 254, 583-605

Herngreen, G.F.W., de Boer, K.F., 1974. Palynologyof Rhaetian, Liassic and Dogger strata in the Eastern Netherlands. Geol. Mijnbouw 53 (6), 343-368.

Herrero, C., Canales, M.L., 1997. Diversidad en los foraminiferos del tránsito Toarciense/ Aaleniense en la sección de Fuentelsaz (Cordillera Ibérica). Rev. Esp. Paleontol. 12, 233-242.

Hoelstad, T., 1985. Palynology of the uppermost l.ower to Middle Jurassic strata on Bornholm, Denmark. Bull. Geol. Soc. Denmark 34, 111-132.

Jacobson, G.L., Bradshaw, R.H.W., 1981. The selection of sites from paleovegetation studies. Quatern. Res. 16, 80-96.

Koppelhus, E.B., Batten, D.J., 1996. Chapter 20C. Application of a palynomorph zonation to a series of short borehole sections, Iower to Middle Jurassic, Øresund, Denmark In: Jansonius, J., McGregor, D.C. (Eds.), Palynology: Principles and Applications: Am Assoc. Stratigr. Palynol. Found, vol. 2, pp. 779-793.

Liu, Z., 2000. Jurassic palynofloras and their bearing on stratigraphic correlation in China. In: Song, Z. (Ed.), Palynofloras and Palynomorphs of China. Contr. 10th Int Palynol. Congr., Univ. Sci. Technol. China Press, Hefei, pp. 53-75.

l.und, J.J., Pedersen, K.R., 1985. Palynology of the marine Jurassic formations in the Vardekløft ravine, Jameson l.and, East Greenland. Bull. Geol. Soc. Denmark 33, 371-399.

Martin, R.E., 1996. Secular increase in nutrient levels through the Phanerozoic: implications for productivity, biomass, diversity of the marine biosphere. Palaios $11,209-219$

Martínez, G., 1992. Hammatoceratinae (Ammonitina) del Toarciense superior y Aaleniense en la Cordillera Ibérica. PhD Thesis no. 374/92, Fac. CC. Geol., Univ. Complutense Madrid, Spain. 331pp.

Martínez, M.A., Quattrocchio, M.E., Sarjeant, W.A.S., 2001. Análisis palinostratigráfico de la Formación l.ajas, Jurásico Medio de la Cuenca Neuquina, Argentina. Rev. Esp. Micropaleontol. 33 (1), 33-60.

Mohr, B.A.R., 1989. New palynological information on the age and environment of late Jurassic and Early Cretaceous vertebrate localities of the Iberian Peninsula (eastern Spain and Portugal). Berl. Geowiss. Abh, Reihe A Geol. Paläontol. 106, 291-301.

Mohr, B., Schmidt, D., 1988. The Oxfordian/Kimmeridgian boundary in the region of Porto de Mòs (Central Portugal): stratigrapy, facies and Palynology. N. Jb. Geol. Paläontol Abh. 176 (2), 245-267.

Mohr, B., Schultka, S., 2000. The flora of the Guimarota mine. In: Martin, T., Krebs, B. (Eds.), Guimarota-A Jurassic Ecosystem. Verlag Dr. Friedrich Pfeil, Mïnchen, pp. 27-32.

Mussard, J.M., Ducazeaux, J., Cugny, P., 1997. Statistical analyses of palynomorph assemblages in Middle Jurassic deposits (lower to Middle Bathonian, Brent Group Norway). Bull. Centres Rech. Explor.-Prod. Elf-Aquitaine 21 (1), 265-277.

Nguyen Tu, T.T., Bocherens, H., Mariotti, A., Baudin, F., Pons, D., Broutin, J., Derenne, S. l.argeau, $\mathrm{Cl}$., 1999. Ecological distribution ofCenomanian terrestrial plants based on ${ }^{13} \mathrm{C} /{ }^{12} \mathrm{C}$ ratios. Palaeogeogr. Palaeoclimat. Palaeoecol. $145,79-93$

Nilsson, T. 1958. Über das Vorkommen eines Mesozoischen Sapropelgesten in Schonen. l.und. Univ. Arsskr. N.F. 2, Bd. 54, 10, 1-112.

Pantić, N.K., 1981. Macroflora and palynomorphs from Iower Jurassic of Budoš Mountain, Montenegro. Ann. Géol. Pen. Balk. 45, 157-169.

Perilli, N., 1999. Calcareous nannofossil biostratigraphy of Toarcian-Aalenian transition at Fuentelsaz section (Iberian Range, East Spain). Cuad. Geol. Ibérica 25, 189-212.

Peyrot, D., Barrón, E., Comas-Rengifo, M.J., Thouand, E., Tafforeau, P., 2007a. A confocal laser scanning and conventional wide field light microscopy study of Classopollis from the Toarcian-Aalenian of the Fuentelsaz section (Spain). Grana 46, 217-226.

Peyrot, D., Rodríguez-López, J.P., Iassaletta, L., Meléndez, N., Barrón, E., 2007b. Contributions to the palaeoenvironmental knowledge of the Escucha Formation in the l.ower Cretaceous Oliete Sub-basin, Teruel, Spain. CR Palevol. 6, 469-481.

Pocock, S.A., 1970. Palynology of the Jurassic sediments of Western Canada. Part 1) Terrestrial Species. Palaeontogr. Abt. B 130, 12-72. 
Prauss, M., ligouis, B., l.uterbacher, H., 1991. Organic matter and palynomorphs in the "Posidonienschiefer" (Toarcian, lower Jurassic) of southern Germany. In: Tyson, R.V., Pearson, T.H. (Eds.), Modern and ancient continental shelf anoxia: Geol. Soc. Spec. Publ., 58, pp. 335-351.

Prentice, C., 1988. Records of vegetation in time and space: the principles of pollen analysis. In: Huntley, B., Webb Ill, T. (Eds.), Vegetation History. Kluwer Academia, Dordrecht, pp. 17-24.

Rauscher, R., Schmitt, J.-P., 1990. Recherches palynologiques dans le Jurassique d'Alsace (France). Rev. Palaeobot. Palynol. 62, 107-156.

Rees, P.M., Ziegler, A.M., Valdes, P.J., 2000. Jurassic phytogeography and climates: new data and model comparisons. In: Hubert, B.T., Macl.eod, K.G., Wing, S.L. (Eds.), Warm Climates in Earth History. Cambridge Univ. Press, Cambridge, pp. 297-318.

Reyre, Y., 1967. Intérét paléobotanique et stratigraphique de l'étude palynologique des séries jurassiques et crétacées du Sahara. Rev. Palaeobot. Palynol. 5, 137-143.

Reyre, Y., 1968.Valeur taxinomique de la sculpture de l'exine des pollens fossiles attribués aux Gymnospemes ou aux Chlamydopermes. CR Acad. Sci. Paris 267, 488-490.

Reyre, Y., 1973. Palynologie du Mésozoïque Saharien. Mém. Mus. Nat. Hist. Natur., Nouv. Sér. C, Sci. Terre 27, 1-280.

Riding, J.B., 1983. The palynology of the Aalenian (Middle Jurassic) sediments of Jackdaw Quarry, Gloucestershire, England. Mercian Geol. (2), 111-120.

Riding, J.B., 1984. A palynological investigation of Toarcian to early Aalenian strata from the Blea Wyke area, Ravenscar, North Yorkshire.Proc. Yorks. Geol Soc.45 (1-2), 109-122.

Riley, L.A., 1974. Miospores from the Upper Jurassic of Cabo Espichel. Portugal. Symp. Stratigr. Palynol. Birbal Sahni Inst. Paleobot. Spec. Publ. 3, 33-41.

Schrank, E., 2003. Small acritarchs from the Upper Cretaceous: taxonomy, biological affinities and palaeoecology. Rev. Palaeobot. Palynol. 123, 199-235.

Schulz, E., 1967. Sporenpaläontologische Untersuchungen rëtoliassischer Schichten im Zentralteil des Germanischen Beckens. Paläontol. Abh. B 2, 427-633.

Schulz, E., Mai, D.H., 1966. Erläuterungen zur Tabelle der Stratigraphischen Verbreitung der Sporen und Pollen im Lias und Dogger. Abh. Zentr. Geol. Inst. 8, 21-34.

Schuurman, W.M.L., 1977. Aspects of l.ate Triassic Palynology. 2. Palynology of the "Grès et schiste à Avicula contorta" and "argiles de levallois" (Rhaetian) of Northeastern France and Southern l.uxemburg. Rev. Palaeobot. Palynol. 23, 159-253.

Seidenkrantz, M.-S., Koppelhus, E.B., Ravn-Sorensen, H., 1993. Biostratigraphy and palaeoenvironmental analysis of a Iower to Middle Jurassic succession on Anholt, Denmark. J. Micropalaeontol. 12 (2), 201-218.

Smelror, M., Ärhus, N., Meléndez, G., Iardies, M.D., 1991. A reconnaissance study of Bathonian to Oxfordian (Jurassic) dinoflagellates and acritarchs from the Zaragoza region (NE Spain) and Figueira da Foz (Portugal). Rev. Esp. Micropaleontol. 23, 47-82.

Srivastava, S.K., 1966. Jurassic microflora from Rajasthan, India. Micropaleontology 12 (1), 87-103

Srivastava, S.K., 1987. Jurassic spore-pollen assemblages from Normandy (France) and Germany. Geobios 20, 5-79.

Stover, L.E., Brinkhuis, H., Damassa, S.P., de Verteuil, L., Helby, R.J., Monteil, E., Partridge, A.D., Powell, A.J., Riding, J.B., Smelror, M., Williams, G.L., 1996. Mesozoic-Tertiary dinoflagellates, acritarchs and Prasinophytes. In: Jansonius, J., McGregor, D.C. (Eds.), Palynology: principles and applications: Am. Assoc. Stratigr. Palynol. Found., 2, pp. $641-750$.

Tasch, P., l.ammons, J.M., 1978. Palynology of some lacustrine interbeds of the Antartic Jurassic. Palinología núm. extraord. 1, 455-461. Mesozoic gymnosperms. A review with palaeoclimatological implications. C.R Palevol. 4, 67-77.

Tralau, H., 1968. Botanical investigations into the fossil flora of Eriksdal in Fyledalen, Scania. II. The Middle Jurassic microflora. Sver. Geol. Unders. Ser. C 633, 1-185.

Tralau, H., Artursson, K., 1972. New Middle Jurassic pollen and spores floras from Southern Sweden and the Öresund. Grana 12, 57-63.

Traverse, A., 2007. Paleopalynology, 2nd edition. Springer, Dordrecht. 813pp.

Vakhrameev, V.A., 1991. Jurassic and Cretaceous Floras and Climates of the Earth Cambridge Univ. Press, Cambridge. 318pp.

van de Schootbrugge, B., Bailey, T.R., Rosenthal, Y., Katz, M.E., Wright,J.D., Miller, K.G., FeistBurkhardt, S., Falkowski, P.G., 2005. Early Jurassic climate change and the radiation of organic-walled phytoplankton in the Tethys Ocean. Paleobiology 31, 73-97.

van Erve, A.W., 1977. Palynological investigation in the lower Jurassic of the Vicentinian Alps (Northeastern Italy). Rev. Palaeobot. Palynol. 23, 1-117.

van Erve, A.W., Mohr, B., 1988. Palynological investigations of the Iate Jurassic microflora from the vertebrate locality Guimarota coal mine (leiria, Central Portugal). N.Jb. Geol. Paläontol. Mh. 1988 (4), 246-262.

Van Konijnenburg-Van Cittert, J.H.A., 2002. Ecology of some late Triassic to Early Cretaceous ferns in Eurasia. Rev. Palaeobot. Palynol. 119, 113-124.

Veiga de Oliveira, L.C., Dino, R., Duarte, L.V., Perilli, N., 2007. Calcareous nannofossils and palynomorphs from Pliensbachian-Toarcian boundary in l.usitanian Basin. Portugal. Rev. Brasil. Paleontol. 10, 5-16.

Vera, J.A. (Ed.), 2004. Geología de España. SGE-IGME, Madrid, Spain, p. 890

Vigran, J.O., Thusu, B., 1975. Illustrations and distribution of the Jurassic palynomorphs of Norway. Roy. Norw. Counc. Sci. Ind. Res. (N TNF) Cont. ShelfDiv 65, 1-55.

Visscher, H., Schuurman, W.M.L., van Erve, A.W., 1980. Aspects of a palynological characterization of l.ate Triassic and Early Jurassic "Standard" units of chronostratigraphical classification in Europe. Proc. IV Int. Palynol. Conf. l.ucknow 2, 281-287.

Wagstaff, B.E., Gallagher, S.J., lanigan, K.P., 2006. Iate Cretaceous palynological correlation and environmental analyses of fluvial reservoir facies of the Tuna Field, Gippsland Basin, southeast Australia. Rev. Palaeobot. Palynol. 138, 165-186.

Wall, D., 1965. Microplankton, pollen and spores from the Iower Jurassic in Britain. Micropaleontology 11, 151-190.

Wang, Y., Mosbrugger, V., Zhang, H., 2005. Early to Middle Jurassic vegetation and climatic events in the Qaidam Basin, Northwest China. Palaeogeogr. Palaeoclimat. Palaeoecol. 224, 200-216.

Warrington, G., Harland, R., 1975. Palynology of the Trias and Iower Lias of the larne borehole. Bull. Geol. Surv. Great Brit. 50, 37-49.

Watson, J., 1988. The Cheirolepidiaceae. In: Beck, C.B. (Ed.), Origin and Evolution of Gymnosperms. Columbia University Press, NY, pp. 382-447.

Webster, T.R., 1992. Developmental problems in Selaginella (Selaginellaceae) in an evolutionary context. Ann. Missouri Bot. Gard. 79, 632-647.

Williams, G.L., Bujak, J.P., 1985. Mesozoic and Cenozoic dinoflagellates. In: Bolli, H.M., Sauders, J.P., Perch-Nielsen, K. (Eds.), Plankton Stratigraphy. Cambridge Univ. Press, Cambridge, UK, pp. 847-964.

Ziegler, A.M., Parrish, J.M., Jiping, Y., Gyllenhaal, E.D., Rowley, D.B., Parrish,J. T., Sangyou, N., Bekker, A., Hulver, M.L., 1993. Early Mesozoic phytogeography and climate. In: Allen, J.R.L., Hoskins, B.J., Sellwood, B.W., Spicer, R.A., Valdes, P.J. (Eds.), Palaeoclimates and their Modelling: With Special Reference to the Mesozoic Era. Chapman and Hall, london, pp. 87-97. 